
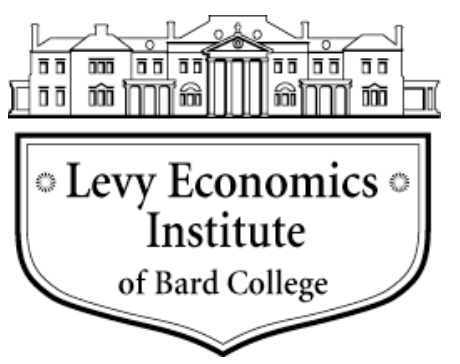

Working Paper No. 589

\title{
Recent Trends in Household Wealth in the United States: Rising Debt and the Middle-Class Squeeze—an Update to 2007
}

by

Edward N. Wolff

Levy Economics Institute of Bard College

March 2010

The Levy Economics Institute Working Paper Collection presents research in progress by Levy Institute scholars and conference participants. The purpose of the series is to disseminate ideas to and elicit comments from academics and professionals.

The Levy Economics Institute of Bard College, founded in 1986, is a nonprofit, nonpartisan, independently funded research organization devoted to public service. Through scholarship and economic research it generates viable, effective public policy responses to important economic problems that profoundly affect the quality of life in the United States and abroad.

Levy Economics Institute

P.O. Box 5000

Annandale-on-Hudson, NY 12504-5000

http://www.levyinstitute.org

Copyright (C) Levy Economics Institute 2010 All rights reserved. 


\begin{abstract}
I find here that the early and mid-aughts (2001 to 2007) witnessed both exploding debt and a consequent “middle-class squeeze.” Median wealth grew briskly in the late 1990s. It grew even faster in the aughts, while the inequality of net worth was up slightly. Indebtedness, which fell substantially during the late 1990s, skyrocketed in the early and mid-aughts; among the middle class, the debt-to-income ratio reached its highest level in 24 years. The concentration of investment-type assets generally remained as high in 2007 as during the previous two decades. The racial and ethnic disparity in wealth holdings, after stabilizing throughout most of the 1990s, widened in the years between 1998 and 2001, but then narrowed during the early and midaughts. Wealth also shifted in relative terms, away from young households (particularly those under age 45) and toward those in the 55-74 age group. Projections to July 2009, made on the basis of changes in stock and housing prices, indicate that median wealth plunged by 36 percent and there was a fairly steep rise in wealth inequality, with the Gini coefficient advancing from 0.834 to 0.865 .
\end{abstract}

Keywords: Household Wealth; Inequality; Racial Inequality; Portfolio Composition

JEL Classifications: D31, J15 


\section{INTRODUCTION}

The 1990s witnessed some remarkable events. The stock market boomed. On the basis of the Standard \& Poor (S\&P) 500 index, stock prices surged 171 percent between 1989 and 2001. Stock ownership spread and by 2001 (as we shall see below) over half of U.S. households owned stock either directly or indirectly. Real wages, after stagnating for many years, finally grew in the late 1990s. According to BLS figures, real mean hourly earnings gained 8.3 percent between 1995 and $2001 .^{1}$

However, 2001 saw a recession (albeit a short one). Moreover, the stock market peaked in 2000 and dropped steeply from 2000 to 2003, but recovered in 2004, so that between 2001 and 2004 the S\&P 500 was down by only 5.3 percent in nominal terms, but 12.0 percent in real terms. ${ }^{2}$ Real wages rose very slowly from 2001 to 2004, with the BLS real mean hourly earnings up by only 1.5 percent, and median household income dropped in real terms by 1.5 percent. ${ }^{3}$ On the other hand, housing prices rose steeply. The median sales price of existing one-family homes rose by 17.9 percent in real terms nationwide. ${ }^{4}$ The other big story was household debt, particularly that of the middle class, which skyrocketed during these years, as we shall see below.

From 2004 to 2007, the stock market rebounded. The S\&P 500 rose 31 percent in nominal terms and 19 percent in real terms. Over the period from 2001 to 2007, the S\&P 500 was up 24 percent in nominal terms and 6 percent in real terms. Real wages remained stagnant, with the BLS real mean hourly earnings rising by only 1.0 percent. Median household income in real terms showed some growth over this period, rising by 3.2 percent. From 2001 to 2007 it gained 1.6 percent. From 2004 to 2007 housing prices slowed, with the median sales price of existing one-family homes nationwide advancing only 1.7 percent over these years in real terms.

\footnotetext{
${ }^{1}$ These figures are based on the Bureau of Labor Statistics (BLS) hourly wage series. The source is table B-47 of the Economic Report, available at: http://www.gpoaccess.gov/eop/tables09.html. The BLS wage figures are converted to constant dollars on the basis of the Consumer Price Index (CPI-U).

${ }^{2}$ The source is table B-96 of the Economic Report of the President, 2009, available at: http://www.gpoaccess.gov/eop/tables09.html. The Census Bureau uses the newer CPI-U-RS series to convert to constant dollars. However, for this period, there is virtually no difference between the CPI-U and the CPI-U-RS.

${ }^{3}$ The source is table B-33 of the Economic Report of the President, 2009, available at: http://www.gpoaccess.gov/eop/tables09.html.

${ }^{4}$ The source is table 935 of the 2009 Statistical Abstract, U.S. Bureau of the Census, available at: http://www.census.gov/compendia/statab/.
} 
Over the years 2001 to 2007 real housing prices gained 18.8 percent.

Most studies have looked at the distribution of well-being or its change over time in terms of income. However, family wealth is also an indicator of well-being, independent of the direct financial income it provides. There are six reasons. First, owner-occupied housing provides services directly to their owner. Second, wealth is a source of consumption, independent of the direct money income it provides, because assets can be converted directly into cash and thus provide for immediate consumption needs. Third, the availability of financial assets can provide liquidity to a family in times of economic stress, such as those occasioned by unemployment, sickness, or family break-up. Fourth, as the work of Conley (1999) has shown, wealth is found to affect household behavior over and above income. Fifth, as Spilerman (2000) has argued, wealth-generated income does not require the same trade-offs with leisure as earned income. Sixth, in a representative democracy, the distribution of power is often related to the distribution of wealth.

Previous work of mine (see Wolff [1994, 1996, 1998, 2001, and 2002a]), using the 1983, 1989, 1992, 1995, and 1998 Surveys of Consumer Finances, presented evidence of sharply increasing household wealth inequality between 1983 and 1989, followed by a modest rise between 1989 and 1998. Both mean and median wealth holdings climbed briskly during the 1983-1989 period. From 1989 to 1998, mean wealth continued to surge while median net worth rose at a rather anemic pace. Indeed, the only segment of the population that experienced large gains in wealth from 1983 to 1998 was the richest 20 percent of households. Moreover, despite the buoyant economy over the 1990s, overall indebtedness continued to rise among American families. Stocks and pension accounts also rose as a share of total household wealth, with offsetting declines in bank deposits, investment real estate, and financial securities.

The ratio of mean wealth between African-American and white families was very low in 1983, at 0.19, and barely budged during the 1990s, though median wealth among AfricanAmerican families did advance relative to white families. In 1983, the richest households were those headed by persons between 45 and 69 years of age, though between 1983 and 1989 wealth shifted away from this age group toward both younger and older age groups. However, the relative wealth holdings of both younger and older families fell between 1989 and 1998.

In this study, I update my earlier analysis on the ownership of household wealth to 2001, 
2004, and 2007. ${ }^{5}$ The next section, section 2, discusses the measurement of household wealth and describes the data sources used for this study. Section 3 presents results on time trends in median and average wealth holdings, section 4 on changes in the concentration of household wealth, and section 5 on the composition of household wealth. Section 6 investigates changes in wealth holdings by race and ethnicity and section 7 reports on changes in the age-wealth profile. Section 8 provides details on stock ownership for different demographic groups. In section 9, I provide a partial update of household wealth trends to 2009. A summary of results and concluding remarks are provided in section 10 .

I find here that the early and mid-2000s (2001 to 2007) witnessed exploding debt and a consequent "middle-class squeeze." Median wealth grew briskly in the late 1990s and even faster in the 2000s. The inequality of net worth was also up slightly during the 2000s. Indebtedness, which fell substantially during the late 1990s, skyrocketed in the early and mid2000s. Among the middle class, the debt-income ratio reached its highest level in 24 years. The concentration of investment-type assets generally remained as high in 2007 as during the previous two decades. The racial and ethnic disparity in wealth holdings, after stabilizing during most of the 1990s, widened in the years between 1998 and 2001, but then narrowed during the early and mid-2000s. Wealth also shifted in relative terms away from young households (particularly under age 45) and toward those in age group 55 to 74.

\section{DATA SOURCES AND METHODS}

The data sources used for this study are the 1983, 1989, 1992, 1995, 1998, 2001, 2004, and 2007 Survey of Consumer Finances (SCF) conducted by the Federal Reserve Board. Each survey consists of a core representative sample combined with a high-income supplement. In 1983, for example, the supplement was drawn from the Internal Revenue Service's Statistics of Income data file. For the 1983 SCF, an income cut-off of $\$ 100,000$ of adjusted gross income was used as the criterion for inclusion in the supplemental sample. Individuals were randomly selected for the sample within predesignated income strata. In later years, the high-income supplement was selected as a list sample from statistical records (the Individual Tax File) derived from tax data by the Statistics of Income Division of the Internal Revenue Service (SOI). This second sample

\footnotetext{
${ }^{5}$ See Wolff (2007) for an earlier update to 2004.
} 
was designed to disproportionately select families that were likely to be relatively wealthy (see, for example, Kennickell [2001] for a more extended discussion of the design of the list sample in the 2001 SCF). The advantage of the high-income supplement is that it provides a much "richer" sample of high income, and therefore potentially very wealthy, families. However, the presence of a high-income supplement creates some complications, because weights must be constructed to meld the high-income supplement with the core sample. ${ }^{6}$

In some years, the SCF also supplied alternative sets of weights. For the 1983 SCF, I use the so-called “Full Sample 1983 Composite Weights” because this set of weights provides the closest correspondence between the national balance sheet totals derived from the sample and those in the Federal Reserve Board Flow of Funds. For the same reason, results for the 1989 SCF are based on the average of SRC-Design-S1 series (X40131 in the database itself) and the SRC design-based weights (X40125); results for the 1992, 1995, 1998, 2001, 2004, and 2007 SCF rely on the design-based weights (X42000) - a partially design-based weight constructed on the basis of original selection probabilities and frame information, adjusted for nonresponse. ${ }^{7}$ In the case of the 1992 SCF, this set of weights produced major anomalies in the size distribution of income for 1991. As a result, I modified the weights somewhat to conform to the size distribution of income as reported in the Internal Revenue Service’s Statistics of Income. ${ }^{8}$

The Federal Reserve Board imputes information for missing items in the SCF. However, despite this procedure, there still remain discrepancies for several assets between the total balance sheet value computed from the survey sample and the flow of funds data. As a result, the results presented below are based on my adjustments to the original asset and liability values in the surveys. This takes the form of the alignment of asset and liability totals from the survey data to the corresponding national balance sheet totals. In most cases, this entails a proportional adjustment of reported values of balance sheet items in the survey data (see Wolff [1987, 1994, 1996, and 1998] for details). ${ }^{9}$ It should be noted that the alignment has very little effect on the

\footnotetext{
${ }^{6}$ For a discussion of some of the issues involved in developing these weights, see Kennickell and Woodburn (1992) for the 1989 SCF; Kennickell, McManus, and Woodburn (1996) for the 1992 SCF; Kennickell and Woodburn (1999) for the 1995 SCF; and Kennickell (2001) for the 2001 SCF.

7 The 1998, 2001, 2004, and 2007 weights are actually partially design-based weights (X42001), which account for the systematic deviation from the CPS estimates of homeownership rates by racial and ethnic groups.

${ }^{8}$ See appendix A for more details.

${ }^{9}$ The adjustment factors by asset type and year are as follows:
} 
measurement of wealth inequality — both the Gini coefficient and the quantile shares. However, it is important to make these adjustments when comparing changes in mean wealth, both overall and by asset type.

The principal wealth concept used here is marketable wealth (or net worth), which is defined as the current value of all marketable or fungible assets less the current value of debts. Net worth is thus the difference in value between total assets and total liabilities or debt. Total assets are defined as the sum of: (1) the gross value of owner-occupied housing; (2) other real estate owned by the household; (3) cash and demand deposits; (4) time and savings deposits, certificates of deposit, and money market accounts; (5) government bonds, corporate bonds, foreign bonds, and other financial securities; (6) the cash surrender value of life insurance plans; (7) the cash surrender value of pension plans, including IRAs, Keogh, and 401(k) plans; (8) corporate stock and mutual funds; (9) net equity in unincorporated businesses; and (10) equity in trust funds. Total liabilities are the sum of: (1) mortgage debt; (2) consumer debt, including auto loans; and (3) other debt.

This measure reflects wealth as a store of value and therefore a source of potential consumption. I believe that this is the concept that best reflects the level of well-being associated with a family's holdings. Thus, only assets that can be readily converted to cash (that is, “fungible” ones) are included. As a result, consumer durables such as automobiles, televisions, furniture, household appliances, and the like are excluded here, since these items are not easily

$\begin{array}{lcccc} & 1983 \text { SCF } & 1989 \text { SCF } & 1992 \text { SCF } & 1995 \text { SCF } \\ & -1.68 & & & \\ \begin{array}{l}\text { Checking Accounts } \\ \text { Savings and Time Deposits }\end{array} & 1.50 & & & \\ \begin{array}{l}\text { All Deposits } \\ \text { Financial Securities }\end{array} & 1.20 & 1.37 & 1.32 & \\ \begin{array}{l}\text { Stocks and Mutual Funds } \\ \text { Trusts }\end{array} & 1.06 & & & \\ \begin{array}{l}\text { Stocks and Bonds } \\ \text { Non-mortgage Debt }\end{array} & 1.16 & 1.66 & 1.41 & 1.45 \\ & & & & 1.23\end{array}$

No adjustments were made to other asset and debt components or to the 1998, 2001, 2004, or 2007 SCF. 
marketed (with the possible exception of vehicles) or their resale value typically far understates the value of their consumption services to the household. Another justification for their exclusion is that this treatment is consistent with the national accounts, where the purchase of vehicles is counted as expenditures, not savings. Also excluded is the value of future social security benefits the family may receive upon retirement (usually referred to as “social security wealth”), as well as the value of retirement benefits from private pension plans (“pension wealth”). Even though these funds are a source of future income to families, they are not in their direct control and cannot be marketed. ${ }^{10}$

I also use a more restricted concept of wealth, which I call "non-home wealth.” This is defined as net worth minus net equity in owner-occupied housing (the primary residence only). Non-home wealth is a more liquid concept than marketable wealth, since one's home is difficult to convert into cash in the short term. Moreover, primary homes also serve a consumption purpose besides acting as a store of value. Non-home wealth thus reflects the resources that may be immediately available for consumption expenditure or various forms of investments.

I use the standard price deflator, the CPI-U, which the U.S. Bureau of Labor Statistics (BLS) has been computing since 1947, to deflate wealth values. The CPI-U has been criticized for overstating the rate of inflation. As a result, the BLS also provides an alternative consumer price series called the CPI-U-RS. ${ }^{11}$ The CPI-U-RS series makes quality adjustments for housing units and consumer durables, such as automobiles and personal computers, and employs a geometric mean formula to account for consumer substitution within CPI item categories. As a result, the CPI-U-RS deflator is not subject to the same criticisms as the CPI-U series. Indeed, the Current Population Survey (CPS) data are now normally deflated to constant dollars by the U.S. Bureau of the Census using the CPI-U-RS price index.

While the CPI-U-RS deflator incorporates quality and other adjustments, the adjustments are made only from 1978 to the present. The CPI-U index is used for years prior to 1978. The CPIU-RS shows a much slower rate of inflation after 1973 than the CPI-U: 288 versus 238 percent. If we use the CPI-U-RS deflator, then constant-dollar median family income would show a 22 percent growth between 1973 and 2000, in comparison to the 6 percent growth rate on the basis of

\footnotetext{
${ }^{10}$ See Wolff (2002b) for estimates of social security and pension wealth.

11 The "RS" stands for "research series."
} 
the CPI-U deflator.

While the use of the CPI-U-RS will show a higher growth in real incomes (and wealth) since 1978, it is not clear that the degree of bias in the CPI has risen in recent years. If similar adjustments were made on the pre-1978 price data, it is possible that the inflation rate over the 1947-1978 period would be adjusted downward by a similar amount as the post-1978 inflation rate. Since my aggregate time-series data on wealth begin in 1922 and I have made calculations of household wealth trends on the basis of micro-data beginning in 1962, I have elected to use the CPI-U series to convert nominal values to real dollars to be consistent with my earlier work on the subject, since the CPI-U series is the only consumer price series that runs from 1922 to the $^{\text {present. }^{12}}$

\section{MEDIAN WEALTH ROSE BRISKLY DURING THE 2000s}

Table 1 documents a robust growth in wealth during the 1990s. Median wealth (the wealth of the households in the middle of the distribution) was 16 percent greater in 2001 than in 1989. After rising by 7 percent between 1983 and 1989, median wealth fell by 17 percent from 1989 to 1995 and then rose by 39 percent from 1995 to 2001. As a result, median wealth grew slightly faster between 1989 and 2001, 1.32 percent per year, than between 1983 and 1989, at 1.13 percent per year. However, between 2001 and 2004, median wealth fell by 0.7 percent, a result of the 2001 recession. Such a drop is not unprecedented. Indeed, it occurred during the last recession in 1992, when median wealth fell by a staggering 15 percent from 1989 to 1992. It was not until 1998 that median wealth surpassed its previous high in 1989. However, from 2004 to 2007 there was a sharp recovery in median wealth, which grew by a sizeable 19.9 percent. Thus, over the 2001-2007 period it increased by 19.1 percent, even faster than during the 1990s (and 1980s).

On the surface it seems rather surprising that median wealth fell from 2001 to 2004 when housing prices rose so rapidly and increased so fast from 2004 to 2007 when housing prices essentially stagnated. As shown in section 5, houses comprise the majority of the wealth of middle-class families (almost exactly two-thirds of the gross assets of the middle three wealth quintiles). Just from the increase in housing prices alone, median net worth should have risen by about 11.8 percent between 2001 and 2004 (the decline in stock prices would have lowered 
median net worth by 0.9 percent, for a net gain of almost 11 percent over this period). The reason why median net worth failed to increase was the enormous increase of household debt of the middle class over these three years (see section 5, below). The surge in median wealth from 2004 to 2007 is a bit of a mystery. The spike in stock prices accounted for only a small part of the increase (about 1.4 percentage points). There was also a slight decline in the debt-to-asset ratio of the middle three wealth quintiles (see table 7). The remaining possibility is that middle-class savings expanded over these years.

As shown in the third row of panel $\mathrm{A}$ in table 1, the percentage of households with zero or negative net worth increased from 15.5 percent in 1983 to 17.9 percent in 1989, but fell off a bit to 17.6 percent in 2001 and then to 17.0 percent in 2004. However, this was followed by a sharp increase in 2007, to 18.6 percent, its highest level over the 24 years. On the other hand, the share of households with net worth less than $\$ 5,000$ and less than $\$ 10,000$ (both in 1995 dollars) declined somewhat between 1989 and 2007.

Mean net worth also showed a sharp increase from 1983 to 1989, followed by a rather precipitous decline from 1989 to 1995, then, buoyed largely by rising stock prices, another surge in 2001, and then an additional rise in both 2004 and 2007. Overall, its 2007 value was almost double its value in 1983 and about three-quarters larger than in 1989. Mean wealth grew quite a bit faster between 1989 and 2001, at 3.02 percent per year, than from 1983 to 1989, at 2.27 percent per year. There was then a slight increase in wealth growth from 2001 to 2007 to 3.10 percent per year. This modest acceleration was due largely to the rapid increase in housing prices of 18.8 percent in real terms over the six years, counterbalanced by the reduced growth in stock prices between 2001 and 2007 in comparison to 1989 to 2001, and to the fact that housing comprised 28.2 percent and (total) stocks made up 24.5 percent of total assets in 2001. Another point of note is that mean wealth grew more-about twice as fast as the median between 1983 and 2007_-indicating widening inequality of wealth over these years.

Non-home wealth grew even faster than net worth during the 1990s. Median non-home wealth rose by 18 percent between 1983 and 1989, then plummeted by 24 percent from 1989 to 1995, and then surged over the next six years for a net increase of 53 percent between 1989 and 2001. However, from 2001 to 2004 median non-home wealth plummeted once again-in this case, by 27 percent. Here, again, the reasons are falling stock prices and rising non-mortgage

\footnotetext{
${ }^{12}$ See, for example, Wolff $(1987,1994$, and 2002a).
} 
debt as a share of total assets. However, from 2004 to 2007 median non-home wealth recovered again and grew by 18 percent, reflecting the recovery of stock prices and the slight reduction in household debt. All in all, median non-home wealth fell by 14 percent from 2001 to 2007, but increased by 57 percent from 1983 to 2007, about 10 percentage points more than the gain in median net worth.

Between 1983 and 1995, the fraction of households with zero or negative non-home wealth expanded from 25.7 to 28.7 percent, then fell back to 25.5 percent in 2001, but then climbed again, to 28.0 percent in 2004, before falling slightly to 27.4 percent in 2007 . Thus, the sharp decline in median non-home wealth from 2001 to 2007 reflected, in part, the growing nonmortgage debt of the bottom half of the distribution.

Mean non-home wealth, after increasing by 18 percent from 1983 to 1989, declined by 8 percent between 1989 and 1995, and then jumped after that, for a net gain of 51 percent between 1989 and 2001. From 2001 to 2004 there was virtually no change in mean non-home wealth, but from 2004 to 2007 there was robust growth, with mean non-home wealth advancing by 14 percent, so that over the entire 1983-2007 period mean non-home wealth increased by 104 percent, slightly more than mean net worth. Increases were almost identical for median and mean non-home wealth from 1983 to 2001, but because of the sharp fall-off in median non-home wealth from 2001 to 2007, mean non-home wealth grew at about double the pace of median nonhome wealth from 1983 to 2007. The bull market in stocks was largely responsible for the sharp growth in non-home wealth between 1995 and 2001, while the slow rise in stock prices coupled with rising indebtedness caused the slow growth in average non-home wealth from 2001 to 2007. Median household income (based on Current Population Survey data), after gaining 11 percent between 1983 and 1989, grew by only 2.3 percent from 1989 to 2001, then dipped by 1.6 percent between 2001 and 2004, but gained 3.2 percent from 2004 to 2007, for a net change of 16 percent from 1983 to 2007. In contrast, mean income rose by 16 percent from 1983 to 1989, by another 12 percent from 1989 to 2001, then fell by 2.6 percent from 2001 to 2004, but gained 1.9 percent from 2004 to 2007, for a net change of -0.8 percent from 2001 to 2007 and a total change of 28 percent from 1983 to 2007. Between 1983 and 2007, mean income grew less than mean net worth (and non-home wealth) and median income grew at a much slower pace than median wealth.

In sum, while household income virtually stagnated for the average American household 
over the 1990s and 2000s, median net worth, and especially median non-home wealth, grew strongly over this period. In the 2000s in particular, mean and median income changed very little while mean and median net worth grew strongly, as did mean non-home wealth, though median non-home wealth tumbled by 14 percent.

\section{WEALTH INEQUALITY SHOWS A MODEST INCREASE OVER THE EARLY 2000s}

The figures in table 2 also show that wealth inequality, after rising steeply between 1983 and 1989, remained virtually unchanged from 1989 to 2007. The share of wealth held by the top 1 percent rose by 3.6 percentage points from 1983 to 1989 and the Gini coefficient increased from 0.80 to 0.83 . Between 1989 and 2007, the share of the top percentile actually declined sharply, from 37.4 to 34.6 percent, though this was more than compensated for by an increase in the share of the next four percentiles. As a result, the share of the top five percent increased from 58.9 percent in 1989 to 61.8 percent in 2007, and the share of the top quintile rose from 83.5 to 85.0 percent. The share of the fourth and middle quintiles each declined by about a percentage point from 1989 to 2007, while that of the bottom 40 percent increased by almost 1 percentage point. Overall, the Gini coefficient was virtually unchanged—0.832 in 1989 and 0.834 in 2007.

Non-home wealth was even more concentrated than net worth, with the richest 1 percent (as ranked by non-home wealth) owning 43 percent of total household non-home wealth in 2007 (compared to 35 percent for net worth) and the top 20 percent owning 93 percent (compared to 85 percent for net worth). The inequality of non-home wealth shows a different time trend than net worth. The share of the top 1 percent gained 4.0 percentage points and the Gini coefficient increased from 0.89 to 0.93 between 1983 and 1989 — trends mirroring those of net worth. However, in the ensuing twelve years (from 1989 to 2001) the share of the richest 1 percent plummeted by seven percentage points, the share of the top 5 percent fell by 3 percentage points, and that of the top quintile by 2 percentage points. The share of the fourth quintile increased by 0.4 percentage points, the share of the middle quintile held its own, and that of the bottom two quintiles rose. As a result, the Gini coefficient fell from 0.93 in 1989 to 0.89 in 2001 and was actually slightly lower in 2001 than in 1983. However, the trend reversed between 2001 and 2007, with the share of the top 1 percent rising by 3.0 percentage points, that of the top quintile up by 1.7 percentage points, and the shares of the third and fourth quintiles, as well as the bottom 
40 percent, all falling. As a result, the Gini coefficient rose from 0.89 in 2001 to 0.91 in 2007, still higher than in 1983, but lower than its peak value in 1989. The run-up in inequality in the 2000s was a reflection of the increase in the share of households with zero or negative non-home wealth.

The top 1 percent of families (as ranked by income on the basis of the SCF data) earned 21 percent of total household income in 2006 and the top 20 percent accounted for 61 percentlarge figures, but lower than the corresponding wealth shares. ${ }^{13}$ The time trend for income inequality also contrasts with those for net worth and non-home wealth inequality. Income inequality increased sharply between 1982 and 1988, with the Gini coefficient rising from 0.48 to 0.52 and the share of the top 1 percent from 12.8 to 16.6 percent. There was then very little change between 1988 and 1997. While the share of the top 1 percent remained at 16.6 percent of total income, the share of the next 19 percent increased by 0.6 percentage points and the share of the other quintiles lost, so that the Gini coefficient grew slightly from 0.52 to 0.53 .

However, between 1997 and 2000, income inequality again surged, with the share of the top percentile rising by 3.4 percentage points, the shares of the other quintiles falling again, and the Gini index advancing from 0.53 to 0.56 . As a result, the years from 1989 to 2001 saw almost the same degree of increase in income inequality as the $1983-1989$ period. ${ }^{14}$ The trend reversed between 2000 and 2003, with the Gini coefficient falling from 0.56 to 0.54 (though still above its 1997 level). The main change was a sharp decline in the share of the top 1 percent by 3 percentage points, reflecting a substantial downturn in realized capital gains. However, the trend reversed from 2003 to 2007. The share of the top 1 percent surged from 17.0 to 21.3 percent of total income, the share of the top quintile from 57.9 to 61.4 percent, the shares of the other quintiles fell, and the Gini coefficient rose sharply from 0.54 to 0.57 . All in all, the 2000s witnessed a moderate increase in income inequality, a small rise in wealth inequality, and a

\footnotetext{
${ }^{13}$ It should be noted that the income in each survey year (say 2007) is for the preceding year (2006 in this case).

${ }^{14}$ It should be noted that the SCF data show a much higher level of income inequality than the CPS data. In the year 2000, for example, the CPS data show a share of the top 5 percent of 22.1 percent and a Gini coefficient of 0.462 . The difference is primarily due to three factors. First, the SCF oversamples the rich (as noted above), while the CPS is a representative sample. Second, the CPS data are top-coded (that is, there is an open-ended interval at the top, typically at $\$ 75,000$ or $\$ 100,000$ ), whereas the SCF data are not. Third, the income concepts differ between the two samples. In particular, the SCF income definition includes realized capital gains, whereas the CPS definition does not. However, the CPS data also show a large increase of inequality between 1989 and 2000, with the share of the top 5 percent rising from 18.9 to 22.1 percent and the Gini coefficient from 0.431 to 0.462 . Further analysis of the difference in income figures between the two surveys is beyond the scope of this paper.
} 
significant jump in non-home wealth inequality.

It is somewhat surprising that net worth inequality did not decline from 2001 to 2004. The reason is that, as shown in my previous work (Wolff 2002a), wealth inequality is positively related to the ratio of stock prices to house prices. Between 2001 and 2004, that ratio (of the Standard \& Poor 500 stock index to the median sales price of existing one-family homes) fell sharply from 8.1 to 6.1 . The reason inequality did not fall is that household debt also mushroomed over these years (see section 5 , below). In fact, the inequality of gross assets did show a decline between 2001 to 2004, from a Gini coefficient of 0.774 to 0.767 . It was only rising debt that led to a rise in overall net worth inequality. Likewise, from 2004 to 2007, we would have expected a larger rise in net worth inequality since income inequality was up sharply and the ratio of S\&P 500 stock index to the median sales price of existing one-family homes rose from 6.1 to 7.1. Again, the reasons are not apparent for the small rise in wealth inequality over these last three years.

Despite the relative stability in overall wealth inequality during the 1990s, there was a near explosion in the number of very rich households (see table 3). The number of millionaires almost doubled between 1989 and 2001, the number of "penta-millionaires" (\$5,000,000 or more) increased three and a half times, and the number of "deca-millionaires" ( $\$ 10,000,000$ or more) grew more than fivefold. Much of the growth occurred between 1995 and 2001 and was directly related to the surge in stock prices. The number of the very rich continued to increase between 2001 and 2007 at about the same pace, with the number of millionaires growing by 23 percent, the number of penta-millionaires by 37 percent, and the number of deca-millionaires by 37 percent as well.

Table 4 shows the absolute changes in wealth and income between 1983 and 2007. The results are even more striking. Over this period, the largest gains in relative terms were made by the wealthiest households. The top 1 percent saw their average wealth (in 2007 dollars) rise by over 9 million dollars or by 103 percent. The remaining part of the top quintile experienced increases from 81 to 142 percent and the fourth quintile by 71 percent. While the middle quintile gained 50 percent, the poorest 40 percent lost 63 percent! By 2007, their average wealth had fallen to $\$ 2,200$.

Another way of viewing this phenomenon is afforded by calculating the proportion of the total increase in real household wealth between 1983 and 2007 accruing to different wealth 
groups. This is computed by dividing the increase in total wealth of each percentile group by the total increase in household wealth, while holding constant the number of households in that group. If a group's wealth share remains constant over time, then the percentage of the total wealth growth received by that group will equal its share of total wealth. If a group's share of total wealth increases (decreases) over time, then it will receive a percentage of the total wealth gain greater (less) than its share in either year. However, it should be noted that in these calculations, the households found in each group (say the top quintile) may be different in the two years.

The results indicate that the richest 1 percent received over one-third of the total gain in marketable wealth over the period from 1983 to 2007. The next 4 percent also received about a third of the total gain and the next 15 percent about a fifth, so that the top quintile collectively accounted for 89 percent of the total growth in wealth, while the bottom 80 percent accounted for 11 percent.

The pattern of results is similar for non-home wealth. The average non-home wealth of the richest 1 percent more than doubled, that of the next richest 4 percent rose by over 150 percent, and that of the next richest 15 percent increased by about 97 percent. Altogether, the non-home wealth of the top quintile gained 123 percent. However, in the case of non-home wealth, the fourth and third quintiles also showed substantial gains, of 87 and 67 percent, respectively, though the bottom 40 percent showed negative growth. Of the total growth in nonhome wealth between 1983 and 2007, 43 percent accrued to the top 1 percent and 94 percent to the top quintile, while the bottom 80 percent collectively accounted for only 6 percent.

A similar calculation using income data reveals that the greatest gains in real income over the period from 1982 to 2006 were made by households in the top 1 percent of the income distribution, who saw their incomes grow by 127 percent. Mean incomes increased by almost two-thirds for the next 4 percent, by about a third for the next highest 5 percent, and by 27 percent for the next highest 10 percent. Groups in the bottom 80 percent of the income distribution all experienced 13 percent or less real growth in income. Of the total growth in real income between 1982 and 2006, 44 percent accrued to the top 1 percent and 87 percent to the top quintile, with remaining 13 percent distributed among the bottom 80 percent.

These results indicate rather dramatically that despite the relative stability of inequality of net worth and the slight decline of non-home wealth inequality during the 1990s and early 
2000s, the growth in the economy during the period from 1983 to 2007 was concentrated in a surprisingly small part of the population - the top 20 percent and particularly the top 1 percent.

\section{STOCKS REMAIN HIGHLY CONCENTRATED IN THE HANDS OF THE RICH}

The portfolio composition of household wealth shows the forms in which households save. In 2007, owner-occupied housing was the most important household asset in the breakdown shown in table 5, accounting for 33 percent of total assets. However, net home equity-the value of the house minus any outstanding mortgage-amounted to only 21 percent of total assets. Real estate, other than owner-occupied housing, comprised 11 percent and business equity another 20 percent. Demand deposits, time deposits, money market funds, CDs, and the cash surrender value of life insurance made up 7 percent and pension accounts 12 percent. Bonds and other financial securities amounted to 2 percent; corporate stock, including mutual funds, to 12 percent; and trust equity to 2 percent. Debt as a proportion of gross assets was 15 percent and the debt-equity ratio (the ratio of total household-debt-to-net worth) was 0.18 .

There have been some notable changes in the composition of household wealth over the period between 1983 and 2007. The first is the steep rise in the share of gross housing wealth in total assets. After fluctuating between 28.2 and 30.4 percent from 1983 to 2001, the ratio jumped to 33.5 percent in 2004 and then declined slightly to 32.8 percent in 2007. There are two factors behind this. The first is the rise in the homeownership rate. According to the SCF data, the homeownership rate, after falling from 63.4 percent in 1983 to 62.8 percent in 1989, picked up to 67.7 percent in 2001 and then to 69.1 percent in 2004 before falling slightly to 68.6 percent in 2007. The second is the sharp rise in housing prices, noted above. Between 2001 and 2004, the median house price for existing one-family homes rose by 17.9 percent in real terms. The rise in housing prices by itself would have caused the share of housing in total assets to rise by 5.05 percentage points, compared to the actual increase of 5.2 percentage points. ${ }^{15}$

A second and related trend is that net equity in owner-occupied housing (the difference between the market value and outstanding mortgages on the property), after falling almost continuously from 23.8 percent in 1983 to 18.2 percent in 1998, picked up to 18.8 percent in 2001, 21.8 percent in 2004, and then 21.4 percent in 2007. The difference between the two series 
(gross versus net housing values as a share of total assets) is attributable to the changing magnitude of mortgage debt on homeowner's property, which increased from 21 percent in 1983 to 37 percent in 1998, fell back to 33 percent in 2001, and then rose again to 35 percent in 2004 and 2007. Moreover, mortgage debt on principal residences climbed from 9.4 to 11.4 percent of total assets between 2001 and 2007. The fact that net home equity as a proportion of assets increased between 2001 and 2007 reflected the strong gains in real estate values over these years.

Third, overall indebtedness first increased, with the debt-equity ratio leaping from 15.1 percent in 1983 to 19.4 percent in 1995, before falling off to 17.6 percent in 1998 and 14.3 percent in 2001. However, it jumped to 18.4 percent in 2004, close to its previous 1992 high, though it fell off slightly to 18.1 percent in 2007. Likewise, the ratio of debt-to-total-income first surged from 68 percent in 1983 to 91 percent in 1995, leveled off in 1998, then declined to 81 percent in 2001, then skyrocketed to 115 percent in 2004 and 119 percent in 2007, its high for this period. If mortgage debt on the principal residence is excluded, then the ratio of other debtto-total-assets fell off from 6.8 percent in 1983 to 3.1 percent in 2001, but then rose to 3.9 percent in both 2004 and 2007. One implication is that over the 1990s and 2000s families used tax-sheltered mortgages and home equity loans rather than consumer loans and other forms of consumer debt to finance consumption.

A fourth change is that pension accounts rose from 1.5 to 12.1 percent of total assets from 1983 to 2007. This increase largely offset the decline in the share of liquid assets in total assets, from 17.4 to 6.6 percent, so that it is reasonable to conclude that households have, to a large extent, substituted tax-deferred pension accounts for taxable savings deposits.

Fifth, the proportion of total assets in the form of other (non-home) real estate fell off sharply, from 15 percent in 1983 to 10 percent in 2001, but then increased to 11.3 percent in 2007. The change from 2001 to 2007 (particularly 2001 to 2004) to a large extent reflected rising real estate prices. Financial securities fell from 4.2 to 1.5 percent of total assets between 1983 and 2007. Unincorporated business equity fell slightly as a share of gross wealth over the years 1983 to 2004, but then surged to 20.1 percent in 2007. The share of corporate stock and mutual funds in total assets rose rather briskly from 9.0 in 1983 to 14.8 percent in 1998, stayed at 14.8 percent in 2001, and then plummeted to 11.8 percent in 2007. If we include the value of stocks indirectly owned through mutual funds, trusts, IRAs, 401(k) plans, and other retirement

\footnotetext{
${ }^{15}$ As noted above, housing prices were essentially flat from 2004 to 2007.
} 
accounts, then the value of total stocks owned as a share of total assets more than doubled from 11.3 percent in 1983 to 24.5 percent in 2001, and then tumbled to 16.8 percent in 2007 . The rise during the 1990s reflected the bull market in corporate equities, as well as increased stock ownership, while the decline in the 2000s was a result of the relatively small rise in the stock market over this period (particularly relative to housing prices), as well as a drop in stock ownership (see table 13b, below). The change in stock prices by itself would have caused the share of total stocks in assets to fall by 2.9 percentage points between 2001 and 2004, compared to the actual decline of 7.0 percentage points. Most of the decline in the share of stocks in total assets was due to sales of stocks and withdrawals from stock funds. ${ }^{16}$

\section{A. Portfolio Composition by Wealth Class}

The tabulation in table 5 provides a picture of the average holdings of all families in the economy, but there are marked class differences in how middle-class families and the rich invest their wealth. As shown in table 6, the richest 1 percent of households (as ranked by wealth) invested over three-quarters of their savings in investment real estate, businesses, corporate stock, and financial securities in 2007. Corporate stocks (either directly owned by the households or indirectly owned through mutual funds, trust accounts, or various pension accounts) comprised 21 percent by themselves. Housing accounted for only 10 percent of their wealth (and net equity in housing 9 percent), liquid assets another 5 percent, and pension accounts another 6 percent. Their ratio of debt-to-net-worth was only 3 percent, their ratio of debt-to-income was 39 percent, and the ratio of mortgage-debt-to-house-value was 15 percent.

Among the next richest 19 percent of U.S. households, housing comprised 32 percent of their total assets (and net home equity 24 percent), liquid assets another 7 percent, and pension assets 16 percent. Forty-four percent of their assets took the form of investment assets—real estate, business equity, stocks, and bonds_-and 19 percent was in the form of stocks directly or indirectly owned. Debt amounted to 12 percent of their net worth and 110 percent of their income, and the ratio of mortgage-debt-to-house-value was 26 percent.

In contrast, almost two-thirds of the wealth of the middle three quintiles of households was invested in their own home in 2007. However, home equity amounted to only 35 percent of

\footnotetext{
${ }^{16}$ However, the rebound in the stock market from 2004 to 2007 would have raised the stock share to 20.8 percent by itself. This was probably offset by increases in asset prices of other assets.
} 
total assets, a reflection of their large mortgage debt. Another 21 percent went into monetary savings of one form or another, as well as pension accounts. Together housing, liquid assets, and pension assets accounted for 86 percent of the total assets of the middle class. The remainder was about evenly split among non-home real estate, business equity, and various financial securities and corporate stock. Stocks directly or indirectly owned amounted to only 7 percent of their total assets. The ratio of debt-to-net-worth was 61 percent, substantially higher than for the richest 20 percent, and their ratio of debt-to-income was 157 percent, also much higher than the top quintile. Finally, their mortgage debt amounted to almost half the value of their principal residences.

Almost all households among the top 20 percent of wealth holders owned their own home, in comparison to 77 percent of households in the middle three quintiles. Though this homeownership rate looks large, 6 percent of households in the middle three quintiles reported having a mobile home as their primary residence. Over three-quarters of very rich households (in the top percentile) owned some other form of real estate (37 percent owned a vacation home), compared to 48 percent of rich households (those in the next 19 percent of the distribution) and only 15 percent of households in the middle 60 percent. Eighty-eight percent of the very rich owned some form of pension asset, compared to 81 percent of the rich and 53 percent of the middle. A somewhat startling 74 percent of the very rich reported owning their own business. The comparable figures are 30 percent among the rich and only 9 percent of the middle class.

Among the very rich, 85 percent held corporate stock, mutual funds, financial securities or a trust fund, in comparison to 63 percent of the rich and 23 percent of the middle. Ninety-three percent of the very rich reported owning stock either directly or indirectly, compared to 86 percent of the rich and 48 percent of the middle. If we exclude small holdings of stock, then the ownership rates drop off sharply among the middle three quintiles, from 48 percent to 32 percent for stocks worth $\$ 5,000$ or more and to 26 percent for stocks worth $\$ 10,000$ or more.

The rather staggering debt level of the middle class in 2007 raises the question of whether this is a recent phenomenon or whether it has been going on for some time. The overall debt-equity ratio in 2007 was still below its peak value in 1995, while the overall debt-income ratio has been generally trending upward since 1983 and actually took a big jump from 2001 to 2004.

Table 7 compares the wealth composition of the three wealth classes in 1983 and 2007. 
There is remarkable stability in the composition of wealth by wealth class between 1983 and 2001. The most notable exception is a substitution of pension assets for liquid assets-a transition that occurred for all three wealth classes, but that was particularly marked for percentiles 80-99 and for the middle three quintiles. The debt-equity ratio actually fell for the top 1 percent from 1983 and 2007, as did the debt-income ratio. The debt-income ratio increased slightly for the next 19 percent, while the debt-income ratio rose sharply, from 73 to 110 percent.

Table 8 shows the wealth composition for the middle three wealth quintiles from 1983 to 2007. Perhaps the noteworthy finding here is that changes in the asset portfolio composition of the middle class basically paralleled those of all households. Houses as a share of total assets remained virtually unchanged from 1983 to 2001, but then increased in 2004, largely a reflection of rising house prices. Pension accounts rose as a share of total assets by almost 12 percentage points (and the proportion of households with a pension account surged by 41 percentage points) from 1983 to 2007, while liquid assets declined as a share by 14 percentage points. This set of changes paralleled that of all households. The share of investment assets in total assets rose by 3 percentage points from 1983 to 2001 and then fell by 2.6 percentage points in 2007, reflecting the stagnation of stock prices. The share of all stocks in total assets mushroomed from 2.4 percent in 1983 to 12.6 percent in 2001 and then fell off to 7 percent in 2007 as stock prices stagnated.

Changes in debt, however, were much more dramatic. There was a sharp rise in the debtequity ratio of the middle class from 37 percent in 1983 to 61 percent in 2007, with most of the increase occurring between 2001 and 2004. The rise was much steeper than for all households. The debt-to-income ratio skyrocketed over this period, more than doubling. Here, too, much of the increase happened between 2001 and 2004. Moreover, the increase was much steeper than for all households. In fact, in 1983, the debt-to-income ratio was about the same for the middle class as for all households, but by 2007 the ratio was much larger. As for all households, net home equity as a percentage of total assets fell for the middle class from 1983 to 2007 and mortgage debt as a proportion of house value rose.

\section{B. Concentration of Assets by Asset Type}

Another way to portray differences between middle-class households and the rich is to compute the share of total assets of different types held by each group (see table 9). In 2007 the richest 1 
percent of households held about half of all outstanding stock, financial securities, trust equity, and business equity, and 28 percent of non-home real estate. The top 10 percent of families as a group accounted for about 85 to 90 percent of stock shares, bonds, trusts, business equity, and non-home real estate. Moreover, despite the fact that 49 percent of households owned stock shares either directly or indirectly through mutual funds, trusts, or various pension accounts, the richest 10 percent of households accounted for 81 percent of the total value of these stocks, somewhat less than its 89 percent share of directly owned stocks and mutual funds.

In contrast, owner-occupied housing, deposits, life insurance, and pension accounts were more evenly distributed among households. The bottom 90 percent of households accounted for 62 percent of the value of owner-occupied housing, 42 percent of deposits, 45 percent of life insurance cash values and 41 percent of the value of pension accounts. Debt was the most evenly distributed component of household wealth, with the bottom 90 percent of households responsible for 73 percent of total indebtedness.

There was relatively little change between 1983 and 2007 in the concentration of asset ownership, with three exceptions. First, the share of total stocks and mutual funds held by the richest 10 percent of households declined from 90 to 85 percent from 1983 to 2004, but then rose back to 89 percent in 2007; their share of stocks directly or indirectly owned fell from 90 percent in 1983 to 79 percent in 2004, but then rose slightly to 81 percent in 2007. Second, the proportion of total pension accounts held by the top 10 percent fell from 68 percent in 1983 to 51 percent in 1989, reflecting the growing use of IRAs by middle-income families, and then rebounded to 59 percent in 2007 from the expansion of 401(k) plans and their adoption by highincome earners. Third, the share of total debt held by the top 10 percent also fell from 32 to 27 percent between 1983 and 2007.

\section{The "Middle-Class Squeeze"}

Nowhere is the middle-class squeeze more vividly demonstrated than in their rising debt. As noted above, the ratio of debt-to-net-worth of the middle three wealth quintiles rose from 37 percent in 1983 to 46 percent in 2001 and then jumped to 61 percent in 2007. Correspondingly, their debt-to-income rose from 67 percent in 1983 to 100 percent in 2001 and then zoomed up to 157 percent in 2007! This new debt took two major forms. First, because housing prices went up over these years, families were able to borrow against the now-enhanced value of their homes by 
refinancing their mortgages and by taking out home equity loans (lines of credit secured by their home). In fact, mortgage debt on owner-occupied housing (principal residence only) climbed from 29 percent in 1983 to 47 percent in 2007, and home equity as a share of total assets actually fell from 44 to 35 percent over these years. Second, because of their increased availability, families ran up huge debt on their credit cards.

Where did the borrowing go? Some have asserted that it went to invest in stocks. However, if this were the case, then stocks as a share of total assets would have increased over this period, which it did not (it fell from 13 to 7 percent between 2001 and 2007). Moreover, it did not go into other assets. In fact, the rise in housing prices almost fully explains the increase in the net worth of the middle class from 2001 to 2007. Of the \$16,400 rise in median wealth, gains in housing prices alone accounted for $\$ 14,000$ or 86 percent of the growth in wealth. Instead, middle-class households, experiencing stagnating incomes, expanded their debt almost exclusively in order to finance consumption expenditures.

The question remains whether the consumption financed by the new debt was simply normal consumption or was there a consumption binge (acceleration) during the 2000s emanating from the expanded debt? That is, did the enhanced debt simply sustain usual consumption or did it lead to an expansion of consumption? To provide an answer, I examine two sources of consumption expenditure data. The first is the personal consumption expenditures data provided in the National Income and Product Accounts (NIPA). ${ }^{17}$ This is the most comprehensive and reliable data on consumption in the United States. However, its drawback from our point of view here is that it covers all households, not just middle-class households. The data show that total personal expenditures grew at 3.38 percent per year from 1989 to 2001, but only 2.93 percent per year from 2001 to 2007. Thus, according to these data, there was actually a modest slowdown in the growth of consumer spending during the 2000s in comparison to the 1990s.

The second source is the Bureau of Labor Statistics’ Consumer Expenditure Survey $(\mathrm{CEX}) .{ }^{18}$ Its advantage is that it provides data on consumer spending by income class group. On the other hand, this data set is subject to sampling error and reporting error. I use the same three years as before. Since the income classes are designated in dollars rather than percentiles, I choose the

\footnotetext{
${ }^{17}$ The data are available from table 1.1 .3 of the national accounts at: http://www.bea.gov/national/nipaweb/TableView.asp?SelectedTable/.

${ }_{18}$ The data are available at: http://www.bls.gov/cex/csxstnd.htm\#2007
} 
income class that lies in the median of the distribution of consumer units in each year. The average expenditure of the median income class was virtually unchanged from 1989 to 2001 and also from 2001 to 2007. Thus, the CEX data, like the NIPA data, show no acceleration in consumer spending during the debt splurge of the 2000s. As a result, it can be concluded that the debt build-up of the 2000s went for normal consumption, not enhanced consumption.

\section{THE RACIAL DIVIDE REMAINS LARGELY UNCHANGED OVER TIME}

Striking differences are found in the wealth holdings of different racial and ethnic groups. In tables 10 and 11, households are divided into three groups: (i) non-Hispanic whites; (ii) nonHispanic African-Americans; and (iii) Hispanics. ${ }^{19}$ In 2007, while the ratio of mean incomes between non-Hispanic white and non-Hispanic black households was an already low 0.48 and the ratio of median incomes was 0.60 , the ratios of mean and median wealth holdings were even lower, at 0.19 and 0.06 , respectively, and those of non-home wealth still lower, at 0.14 and 0.01 , respectively. ${ }^{20}$ The homeownership rate for black households was 49 percent in 2007, a little less than two-thirds the rate among whites, and the percentage of black households with zero or negative net worth stood at 33.4, more than double the corresponding percentage among whites.

Between 1982 and 2006, while the average real income of non-Hispanic white households increased by 42 percent and the median by 10 percent, the former rose by only 28 percent for non-Hispanic black households, but the latter by 18 percent. As a result, the ratio of mean income slipped from 0.54 in 1982 to 0.48 in 2006, while the ratio of median income rose from 0.56 to 0.60 .

Between 1983 and 2001, average net worth (in 2001 dollars) rose by a whopping 73 percent for whites, but only by 31 percent for black households, so that the net worth ratio fell from 0.19 to 0.14. Most of the slippage occurred between 1998 and 2001, when white net worth surged by a spectacular 34 percent and black net worth advanced by only a respectable 5 percent. Indeed, mean net worth growth among black households was slightly higher in the 1998-2001

\footnotetext{
${ }^{19}$ The residual group, American Indians and Asians, is excluded here.

${ }^{20}$ It should be stressed that the unit of observation is the household, which includes both families (two or more related individuals living together), as well as single adults. As is widely known, the share of female-headed households among African-Americans is much higher than that among whites. This difference partly accounts for the relatively lower income and wealth among African-American
} 
years, at 1.55 percent per year, than in the preceding 15 years, at 1.47 percent per year. The difference in the 1998-2001 period was the huge increase in household wealth among white households. However, between 2001 and 2007, mean net worth among black households gained an astounding 58 percent, while white wealth advanced only 29 percent, so that by 2007 the net worth ratio was back to 0.19 , the same level as in 1983 .

It is not clear how much of the sharp drop in the racial wealth gap between 1998 and 2001 and the turnaround between 2001 and 2007 is due to actual wealth changes in the AfricanAmerican community and how much is due to sampling variability (since the sample sizes of non-Hispanic African-Americans are relatively small in all years). However, one salient difference between the two groups is the much higher share of stocks in the white portfolio and the much higher share of principal residences in the portfolio of black households. In 2001, the gross value of principal residences formed 46.3 percent of the gross assets of black households and only 26.9 percent that of white households, while (total) stocks were 25.4 percent of the total assets of whites and only 14.9 percent that of black households. ${ }^{21}$ Moreover, while the debt ratio was higher for black than white households in 2001 (debt-to-asset ratios of 0.324 and 0.115 , respectively), the ratio declined for black households from 0.324 in 2001 to 0.297 in 2004, but then bounced back to 0.356 . For whites the debt-to-asset ratio first rose to 0.140 in 2004, but then fell slightly to 0.134 in 2007.

In the case of median wealth, the black-white ratio first increased from 7 to 12 percent between 1983 and 1998 and then diminished to 10 percent in 2001, where it remained in 2004. In this case, median wealth for white households grew by 25 percent between 1998 and 2004, but by only 2.1 percent among black households. Median wealth among black households actually dipped by 29 percent between 2004 and 2007, reflecting in part the rising share of black households with zero or negative net worth, while it rose by 11 percent among white households, and the ratio of median wealth between blacks and whites fell to 0.06 in 2007, a little less than the ratio in 1983.

Average non-home wealth also increased somewhat more for black than white households between 1983 and 1998, so that the ratio rose from 13 to 15 percent. However, between 1998 and 2001, mean non-home wealth among white households also surged by 34

households.

${ }^{21}$ Also, see Gittleman and Wolff (2004) for additional evidence from the Panel Study of Income Dynamics (PSID). 
percent, but inched up only 6 percent among black households, so that the ratio dwindled back to 0.12 - even lower than in 1983. Once again there was a notable recovery from 2001 to 2004, where mean non-home wealth climbed by 33 percent among blacks, but was virtually unchanged among white households, so that by 2004 the ratio was up to 0.15 , the same level as in 2001 . The ratio then dipped a bit, to 0.14 , in 2007. The reasons are here also the lower share of non-home assets held in the form of stocks by black households and the decrease in their debt ratio over the 2001-2004 period followed by a rise in their debt ratio from 2004 to 2007.

The median non-home wealth of non-Hispanic black households also increased, from virtually zero in 1983 to a positive \$1,100 in 2001, and the corresponding ratio also grew, from zero to 3 percent. However, from 2001 to 2004, median non-home wealth among blacks toppled to only $\$ 300$ and the corresponding ratio fell to only 1 percent. The reason for the decline was the faster growth of debt among black middle-class households than among whites. There followed a slight recover in median non-home wealth among blacks to $\$ 500$ in 2007, but the racial ratio remained at 0.01 .

The homeownership rate of black households grew from 44.3 to 47.4 percent between 1983 and 2001, but relative to white households, the homeownership rate first increased from a ratio of 0.65 in 1983 to 0.67 in 1998 and then slipped to 0.64 in 2001 . The change over the 1998-2001 period primarily reflected a big jump in the white homeownership rate of 2.3 percentage points. However, from 2001 to 2004, the black homeownership rate surged to a little over half, while the white homeownership rate moved up to only 75.8 percent. As a result, the homeownership rate ratio recovered a bit to 0.66 by 2004 . The homeownership rates dropped a bit for both black and white households between 2004 and 2007, and the ratio of homeownership rates fell slightly to 0.65 .

In contrast, the percentage of black households reporting zero or negative net worth fell from 34.1 percent in 1983 to 27.4 percent in 1998 (and likewise declined relative to white households), but then retreated to 30.9 percent in 2001 (and also rose relative to the corresponding rate for white households). ${ }^{22}$ In 2004, the share of black households with nonpositive wealth dipped a bit again, to 29.4 percent, and also fell a bit relative to the

\footnotetext{
${ }^{22}$ There is a large amount of variation in the income and wealth figures for both blacks and Hispanics on a year-by-year basis. This is probably a reflection of the small sample sizes for these two groups and the associated sampling variability, as well as some changes in the wording of questions on race and ethnicity over the eight surveys.
} 
corresponding share of white households. However, in the ensuing three years the share of black households with zero or negative wealth surged again, reaching 33.4 percent in 2007. The share of white households reporting non-positive wealth was also up in 2007 and the black-white ratio also rose a bit from 2004 to 2007.

The picture is somewhat different for Hispanics (see table 11). The ratio of mean income between Hispanics and non-Hispanic whites in 2007 was 0.50, almost the same as that between African-American and white households. However, the ratio of median income was 0.70 , much higher than the 0.60 ratio between black and white households. The ratio of mean net worth was 0.26 compared to a ratio of 0.19 between blacks and whites, and the ratio of mean non-home wealth 0.19 compared to a ratio of 0.14 between blacks and whites. However, the ratios of medians were 0.06 and 0.01 , respectively, almost identical to those between blacks and whites. The Hispanic homeownership rate was 49 percent, almost identical to that of non-Hispanic black households, and 34 percent of Hispanic households reported zero or negative wealth, almost the same as African-Americans.

Progress among Hispanic households over the period from 1983 to 2007 was generally a positive story. Mean household income for Hispanics grew by 18 percent and median household income by 16 percent, so that the ratio of mean income slid from 60 to 50 percent, while that of median income advanced from 66 to 70 percent. In fact, from 2004 to 2007 median income for Hispanics grew by an astonishing 23 percent, while for non-Hispanic whites it declined by 5 percent. $^{23}$

Between 1983 and 1998, mean wealth almost doubled for Hispanic households and mean non-home wealth grew more than fourfold, but between 1989 and 2001 both declined in absolute terms. As a result, the ratio of mean net worth climbed from 16 percent in 1983 to 25 percent in 1998, and then tumbled to 17 percent in 2001; the ratio of mean non-home wealth jumped from 7 to 20 percent between 1983 and 1998 then fell off to 14 percent in 2001. However, both recovered in 2004. Mean net worth among Hispanics climbed by 32 percent between 2001 and 2004 and mean non-home wealth by 22 percent, and the corresponding ratios advanced to 21 percent and 17 percent, respectively. Another wealth surge occurred from 2004 to 2007 for

\footnotetext{
${ }^{23}$ In contrast, according the CPS data, median household income among Hispanics grew by only 4.4 percent from 2003 to 2006 and that among non-Hispanic whites by 0.1 percent. It is not clear why there is such a large discrepancy between the SCF and CPS data.
} 
Hispanics. Mean net worth among Hispanics gained 36 percent, mean non-home wealth advanced by 31 percent, and the corresponding ratios climbed to 26 and 19 percent, respectively_quite a bit higher than those between black and white households.

On the other hand, from 1983 to 2007, median wealth among Hispanics remained largely unchanged, as did median non-home wealth (at virtually zero!), so that the ratio of both median wealth and median non-home wealth between Hispanics and non-Hispanic whites stayed virtually the same. In contrast, the homeownership rate among Hispanic households surged from 33 to 44 percent between 1983 and 1998 and the ratio of homeownership rates between the two groups grew from 0.65 in 1983 to 0.67 in 1998. No progress was made among Hispanics in the homeownership rate between 1998 and 2001, so that the homeownership ratio fell back to 0.60. However, between 2001 and 2007, the Hispanic homeownership rose once again, to 49 percent, about the same as black households, and the homeownership ratio recovered to 0.66.

The percentage of Hispanic households with zero or negative net worth fell rather steadily over time, from 40 percent in 1983 to 31 percent in 2004, and the share relative to white households tumbled from a ratio of 3.01 to 2.41. Here, too, the ratio first spiked upward from 2.1 in 1998 to 2.7 in 2001 before recovering partway to 2.4 in 2004. However, from 2004 to 2007, the share of Hispanics with non-positive wealth rose to 34 percent, almost the same as among black households, though the ratio with white households fell to 2.3.

Despite some progress from 2001 to 2007, the respective wealth gaps between AfricanAmericans and Hispanics on the one hand and non-Hispanic whites on the other were still much greater than the corresponding income gaps in 2007. While mean income ratios were of the order of 50 percent, mean wealth ratios were of the order of 20-25 percent. Median non-home wealth among non-Hispanic black and Hispanic households was still virtually zero in 2007 and the percent with zero or negative net worth was around a third, in contrast to 15 percent among nonHispanic white households (a difference that appears to mirror the gap in poverty rates). While blacks and Hispanics were left out of the wealth surge of the years 1998 to 2001 because of relatively low stock ownership (see section 8 for more details), they actually benefited from this (and the relatively high share of houses in their portfolio) in the 2001-2007 period. However, all three racial/ethnic groups saw an increase in their debt-to-asset ratio from 2001 to $2007 .^{24}$

\footnotetext{
${ }^{24}$ One important reason for the wealth gap is differences in inheritances. According to my calculations from the SCF data, 24.1 percent of white households in 1998 reported receiving an inheritance over their lifetime, compared
} 


\section{WEALTH SHIFTS FROM THE YOUNG TO THE OLD}

As shown in table 12, the cross-sectional age-wealth profiles of 1983, 1989, 1992, 1995, 1998, 2001, 2004, and 2007 generally follow the predicted hump-shaped pattern of the life-cycle model (see, for example, Modigliani and Brumberg [1954]). Mean wealth increases with age up through age 65 or so and then falls off. Non-home wealth has an almost identical profile, though the peak is generally somewhat higher than for net worth. Homeownership rates also have a similar profile, though the fall-off after the peak age is much more attenuated than for the wealth numbers (and in 2004 they actually show a steady rise with age). In 2007, the wealth of elderly households (age 65 and over) was, on average, 75 percent higher than the non-elderly and their homeownership rate was 21 percentage points higher.

Despite the apparent similarity in the profiles, there have been notable shifts in the relative wealth holdings of age groups between 1983 and 2007. The relative wealth of the youngest age group, under 35 years of age, expanded from 21 percent of the overall mean in 1983 to 29 percent in 1989, but then collapsed to only 17 percent in 2007. In 2007, the mean wealth of the youngest age group was $\$ 91,200$, which was only slightly more than the mean wealth of this age group in $1989(\$ 88,500)$. The mean net worth of the next youngest age group, 35-44, relative to the overall mean remained fairly steady at around 0.71 from 1983 to 1992, then dipped to 0.65 in 1995 where it generally remained until 2004, and then tumbled to 0.58 in 2007. The relative wealth of the next youngest age group, 45-54, also declined rather steadily over time, from 1.53 in 1983 to 1.19 in 2007. The relative wealth of age group 55-64 gained rather steadily over time from 1.67 in 1983 to 1.91 in 2004, but then fell to 1.69 in 2007. The relative net worth of age group 65-74 plummeted from 1.93 in 1983 to 1.61 in 1989, regained some of the lost ground, reaching 1.72 in 2001, and then underwent another steep drop to 1.57 in 2004, but again recovered to 1.86 in 2007. The wealth of the oldest age group, age 75 and over, gained substantially, from only 5 percent above the mean in 1983 to 32 percent in 1995, but then

to 11 percent of black households, and the average bequest among white inheritors was $\$ 115,000$ (present value in 1998) and only $\$ 32,000$ among black inheritors. Thus, inheritances appear to play a vital role in explaining the large wealth gap, particularly in light of the fact that black families appear to save more than white families at similar income levels (see, for example, Blau and Graham [1990], Oliver and Shapiro [1997], and Gittleman and Wolff [2004]). 
fell back to 16 percent in 2007, though still above its 1983 level.

Results for non-home wealth are very similar. The average non-home wealth of the youngest age group climbed from 17 to 28 percent of the overall mean from 1983 to 1989 and then plummeted to only 15 percent in 2007. The mean non-home wealth of age groups 45-54 and 65-74 also fell over the 1983-2004 period, whereas that of age group 55-64 rose. Two patterns were somewhat different. The relative mean non-home wealth of age group 35-44 rose from 0.59 in 1983 to 0.68 in 1989 and then declined to 0.54 in 2007, below its 1983 level, while that of the oldest age group rose from 10 percent above the mean in 1983 to 27 percent above the mean in 1983 and then fell back to 10 percent above the mean in 2007 (the same as its 1983 position).

Changes in homeownership rates tend to mirror these trends. While the overall ownership rate increased by 5.2 percentage points from 63.4 to 68.6 percent between 1983 and 2007, the share of households in the youngest age group owning their own home increased by only 2.1 percentage points. The homeownership rate of households between 35 and 44 of age actually fell by 2.3 percentage points, and that of age group 45 to 54 years of age declined by 0.9 percentage points. Big gains in homeownership were recorded by the older age groups: 3.9 percentage points for age group 55-64, 7.1 percentage points for age group 65-74, and 7.6 percentage points for the oldest age group. ${ }^{25}$ By 2007, homeownership rates rose monotonically with age up to age group 65-74 and then dropped for the oldest age group. The statistics point to a relative shifting of homeownership away from younger towards older households between 1983 and 2007.

Changes in the relative wealth position of different age groups depend in large measure on relative asset price movements and differences in asset composition. The latter are highlighted in table 13 for the year 2007. The gross value of the principal residence comprised over half the value of total assets for age group 35 and under; its share of total assets fell off with age to about a quarter for age group 55-64 and then rose to 30 percent for age group 75 and over. Liquid assets as a share of total assets remained relatively flat with the 75 and over age group at around 6 percent, except for the oldest group for whom it was 11 percent, perhaps

\footnotetext{
${ }^{25}$ As with racial minorities, the sample size is relatively small for age group 75 and over, so that the huge increase in the homeownership rate between 2001 and 2004 (almost 9 percentage points) may be ascribable to sampling variation.
} 
reflecting the relative financial conservativeness of older people. Pension accounts as a share of total assets rose from 4 percent for the youngest group to 16 percent for age group 55 to 64 and then fell off to 5 percent for the oldest age group. This pattern likely reflects the build-up of retirement assets until retirement age and then a decline as these retirement assets are liquidated. ${ }^{26}$ Corporate stock and financial securities showed a steady rise with age, from a 4 percent share for the youngest group to a 26 percent share for the oldest. A similar pattern was evident for total stocks as a percentage of all assets. Unincorporated business equity and nonhome real estate was relatively flat as a share of total assets with age, about 30 percent.

There was a pronounced falloff of debt with age. The debt-to-equity ratio declined from 93 percent for the youngest group to 2 percent for the oldest, the debt-to-income ratio from 168 percent to 30 percent, and principal residence debt as a share of house value from 65 to 5 percent. As a result of the latter, net home equity as a proportion of total assets rose from 19 to 29 percent from the youngest to oldest age group.

Younger households were thus more heavily invested in homes and more heavily in debt whereas the portfolio of older households was more heavily skewed to financial assets, particularly corporate stock. As a result, younger households benefit relatively when housing prices rise and inflation is strong, while older households benefit relatively from rising stock prices. Changes in the relative net worth position of age groups over the 1983 to 2007 period were thus largely due to these relative asset price movements.

\section{STOCK OWNERSHIP FIRST RISES AND THEN FALLS}

Tables 14a and 14b report on overall stock ownership trends from 1983 to 2007. The proportion of households who owned corporate stock shares directly declined a bit between 1983 and 1989, from 13.7 to 13.1 percent, while the share that owned any stocks or mutual funds plunged over these years, from 24.4 to 19.9 percent. ${ }^{27}$ In contrast, the share of households owning stocks and mutual funds worth \$5,000 or more (in 1995 dollars) was stable over this period; indeed, the proportion with holdings of $\$ 10,000$ or more and with $\$ 25,000$ or more actually rose over this

\footnotetext{
${ }^{26}$ This pattern may also be partly a cohort effect since 401(k) plans and other defined contribution plans were not widely introduced into the workplace until after 1989.

${ }^{27}$ The 1983 data do not permit an estimation of indirect stock ownership, so that we present the results for 1983 and 1989 separately from the other years.
} 
period. These changes over the 1983-1989 period might reflect the steep drop in the stock market in 1987 and the consequent exit of small fund holders after 1987. Yet, despite a 62 percent real increase in stock prices (as measured by the Standard and Poor 500 index), stocks plus mutual funds as a share of total household asset actually dipped from 9 percent in 1983 to 6.9 percent in 1989.

In contrast, the years 1989 to 2001 saw a substantial increase in stock ownership (see table 14b). The share of households with direct ownership of stock climbed from 13.1 percent in 1989 to 21.3 percent in 2001, while the share with some stock owned either outright or indirectly through mutual funds, trusts, or various pension accounts surged from 31.7 to 51.9 percent. Much of the increase was fueled by the growth in pension accounts like IRAs, Keogh plans, and 401(k) plans. Between 1989 and 2001, the share of households owning stock through a pension account more than doubled, accounting for the bulk of the overall increase in stock ownership. Indirect ownership of stocks through mutual funds also greatly expanded over the 1989-2001 period, from 5.9 to 16.7 percent, as did indirect ownership through trust funds, from 1.6 to 5.1 percent. All told, the share of households with indirect ownership of stocks more than doubled, from 23.5 percent in 1989 to 47.7 percent in 2001.

The next six years, 2001-2007, saw a retrenchment in stock ownership. This trend probably reflected the sharp drop in the stock market from 2000 to 2001, its rather anemic recovery through 2004, and its subsequent rebound from 2004 to 2007. Direct stock ownership declined only slightly from 21.3 percent in 2001 to 20.7 percent in 2004, but then plummeted in 2007 to 17.9 percent. Indirect stock ownership fell by 3.3 percentage points from 2001 to 2007; this was largely due to a sharp decline in stock ownership through mutual funds (down by 6.1 percentage points). Stock ownership through pension accounts was down by 3.4 percentage points from 2001 to 2004, but then rose by 2.2 percentage points from 2004 to 2007 as the stock market recovered.

By 2004 the share of households who owned stock directly or indirectly dipped below half, down to 48.6 percent, about the same level as in 1998 and down from its peak of 51.9 percent in 2001. However, it did increase slightly to 49.1 percent in 2007. Moreover, many of these families had only a minor stake in the stock market in 2007, with only 35 percent with total stock holdings worth $\$ 5,000$ (in 1995 dollars) or more, down from 40 percent in 2001. Only 30 percent owned $\$ 10,000$ or more of stock, down from 35 percent in 2001, and only 22 percent 
owned $\$ 25,000$ or more of stocks, down from 27 percent six years earlier.

Direct plus indirect ownership of stocks as a percent of total household assets did more than double from 10.2 in 1989 to 24.5 in 2001 . This increase may reflect, in large measure, the 171 percent surge in stock prices over these years. However, between 2001 and 2007, the share plummeted to 16.8 percent. This change is a result not only of the relative stagnation of the stock market over these years, but also of the withdrawal of many families from the stock market.

Table 12c shows the distribution of total stocks owned by vehicle of ownership. Here there are very marked time trends. Direct stock holdings as a share of total stock holdings fell almost continuously over time, from 54 percent in 1989 to 37 percent in 2007. The only deviation occurred in 1998, when direct stock ownership took an upward spike. This may reflect the stock market frenzy of the late 1990s. In contrast, stock held in mutual funds as a share of total stock rose almost continuously over time, from 8.5 percent in 1983 to 21 percent in 2007, while that held in trust funds declined by 6 percentage points.

The most interesting pattern is with regard to stock held in pension accounts (including IRAs). Its share of total stocks first increased from 24 percent in 1989 to 38 percent in 1995, but then fell off to 31 percent in 2007. The trend after 1995 seems to reflect a substitution of stock holdings in mutual funds for those in pension plans as investors looked for safer retirement accounts (see below). Likewise the share of the total value of pension plans held as stock more than doubled between 1989 and 1995, from 33 to 68 percent, remained at this level through 2001, and then plummeted to 44 percent in 2007. The sharp tail-off in stock ownership in pension plans between 2001 and 2004 likely reflects the lethargic performance of the stock market over this period (and its precipitous fall from 2000 to 2002) and the search for more secure investments among plan holders.

Stock ownership is also highly skewed by wealth and income class. As shown in table 15a, 93 percent of the very rich (the top 1 percent) reported owning stock either directly or indirectly in 2007, compared to 48 percent of the middle quintile and 16 percent of the poorest 20 percent. While 88 percent of the very rich also reported stocks worth $\$ 10,000$ or more, only 22 percent of the middle quintile and 2 percent of the bottom quintile did so. The top 1 percent of households owned 38 percent of all stocks, the top 5 percent owned 69 percent, the top 10 percent 81 held percent, and the top quintile owned over 90 percent.

Stock ownership also tails-off by income class (see table 15b). Whereas 94 percent of 
households in the top 3.6 percent of income recipients (those who earned $\$ 250,000$ or more) owned stock in 2007, 39 percent of the middle class (incomes between \$25,000 and 50,000), 23 percent of the lower middle class (incomes between $\$ 15,000$ and 25,000), and only 11 percent of poor households (income under $\$ 15,000$ ) reported stock ownership. The comparable ownership figures for stock holdings of $\$ 10,000$ or more are 91 percent for the top income class, 19 percent for the middle class, 12 percent for the lower-middle class, and 4 percent for the poor. Moreover, 84 percent of all stocks were owned by households earning $\$ 75,000$ or more (the top 30 percent) and 92 percent by those earning $\$ 50,000$ or more in terms of income.

Another notable development in the 2000s was an increase in the concentration of stock ownership, as shown in the last column of tables 15a and 15b. The share of total stock owned by the richest 1 percent in terms of wealth increased from 33.5 percent in 2001 to 38.3 percent in 2007 and that of the richest 5 percent from 62.3 to 69.1 percent. In terms of income, the share of total stock owned by the top income class jumped from 40.6 to 53.7 percent (though, it should be noted their share of total households also rose from 2.7 to 3.6 percent) and that of the top two income classes from 68.6 to 75.2 percent. One result of the stock market bust of the early 2000s was a withdrawal of middle-class families from the stock market.

Thus, in terms of wealth or income, substantial stock holdings have still not penetrated much beyond the reach of the rich and the upper middle class. The big winners from the stock market boom of the late 1990s (as well as the big losers in the early 2000s) were these groups, while the middle class and the poor did not see sizable benefits from the bull market (or losses when the stock market tanked in 2000-2002). It is also apparent which groups benefit the most from the preferential tax treatment of capital gains.

\section{AN UPDATE TO 2009}

A complete update of the wealth figures to 2009 is beyond the scope of the present study. However, it is possible to provide a partial update of the wealth figures to July 1, 2009 based on two notable developments. The first is that house prices fell by 23.5 percent in real terms ${ }^{28}$ and

\footnotetext{
${ }^{28}$ This figure is based on the National Association of Realtors Median Sales Price of Existing Single-Family Homes for Metropolitan Areas.
} 
the second is that the S\&P 500 index was down by 40.9 percent in real terms. ${ }^{29}$ A somewhat rough update, based on the change in housing and stock prices, shows a marked deterioration in middle-class wealth. According to my estimates, while mean wealth (in 2007 dollars) fell by 17.3 percent between 2007 and 2009 to $\$ 443,600$, median wealth plunged by an astounding 36.1 percent to $\$ 65,400$ (about the same level as in 1992!).

Trends in inequality are also interesting. According to previous research (Wolff 2002a), wealth inequality is very sensitive and positively related to the ratio of stock-prices-to-housingprices, since the former is heavily concentrated among the rich and the latter is the chief asset of the middle class. ${ }^{30}$ The fact that stock prices fell more than housing prices, at least from 2007 to mid-2009, should lead to a decline in wealth inequality over these two years. However, the results show a fairly steep rise in wealth inequality, with the Gini coefficient climbing from 0.834 to 0.865 . The share of the top 1 percent advanced from 34.6 to 37.1 percent, that of the top 5 percent from 61.8 to 65 percent, and that of the top quintile from 85 to 87.7 percent, while that of the second quintile fell from 10.9 to 10 percent, that of the middle quintile from 4 to 3.1 percent, and that of the bottom two quintiles from 0.2 to -0.8 percent. There was also a large expansion in the share of households with zero or negative net worth, from 18.6 to 24.1 percent.

On the surface, these results appear somewhat surprisingly in light of the earlier regression results. However, while stock prices fell more than house prices, houses were a much larger share of the gross assets of the middle class than stocks were of the rich. As shown in table 6, the gross value of principal residence comprised 65.1 percent of the gross assets of the three middle wealth quintiles in 2007, whereas stocks made up 21.4 percent of the gross assets of the top 1 percent and 18.6 percent of the next 19 percent. As a result, the middle class took a bigger relative hit from the decline in home prices on their net worth than the top 20 percent did from the stock market decline. This is also reflected in the fact that median wealth dropped much more

\footnotetext{
${ }^{29}$ I assume that there are no additional savings (or dissavings) and no portfolio adjustments (except those caused by price changes of homes and stock).

${ }^{30}$ The regression was run of a wealth inequality index, measured by the share of marketable wealth held by the top 1 percent of households (WLTH) on income inequality, measured by the share of income received by the top 5 percent of families (INC), and the ratio of stock prices (the S\&P 500 index) to housing prices (RATIO), with 21 data points between 1922 and 1998. It yields:

$$
\mathrm{WLTH}=\underset{(0.9)}{5.10}+\underset{(4.2)}{1.27 \mathrm{INC}}+\underset{(2.5)}{0.26 \mathrm{RATIO},} \mathrm{R} 2=0.64, \quad \mathrm{~N}=21
$$

with t-ratios shown in parentheses. Both variables are statistically significant (INC at the 1 percent level and RATIO at the 5 percent level) and with the expected (positive) sign. Also, the fit is quite good, even for this simple model.
} 
in percentage terms than mean wealth.

We can see how the rising debt of the middle class made them vulnerable to income shocks and set the stage for the mortgage crises of 2008 and 2009 and the resulting financial meltdown. The rapid decline in house prices over these two years (on the order of 24 percent) left many middle-class families (I estimate 16.6 percent of homeowners) “underwater” (greater mortgage debt than the value of their homes) and, coupled with a sharp spike in unemployment, unable (or unwilling) to repay their mortgage loans. ${ }^{31}$

\section{SUMMARY AND CONCLUDING COMMENTS}

The years 2001 to 2004 witnessed an explosion of household debt and gave evidence of the middle-class squeeze. Median wealth declined by 0.7 percent after a period of robust growth from 1998 to 2001. The only other times in the recent past that median wealth has declined were during recessionary periods. While 2001 was a recession year, 2002-2004 was a period of expansion, so the decline in median wealth was almost unprecedented. Moreover, median nonhome wealth (total wealth less home equity) fell by a staggering 27 percent from 2001 to 2004. While the share of households with non-positive net worth declined slightly, the percent of households with zero or negative non-home wealth rose substantially, by 2.5 percentage points, from 2001 to 2004. Median income also fell by 1.6 percent from 2001 to 2004.

The mid-2000s, from 2004 to 2007, were a period of recovery. Median household income rose by 3.2 percent. From 2004 to 2007 median wealth grew sharply by 19.9 percent. Over the 2001-2007 period it increased by 19.1 percent, even faster than during the 1990s (and 1980s). Median non-home wealth also showed a sizeable increase from 2004 to 2007, by 17.6 percent, though it was down by 13.5 percent over the whole 2001 to 2007 period. However, the share of

\footnotetext{
${ }^{31}$ Two papers that appeared subsequent to the first draft of my paper have also called attention to the growing debt during the 2000s and have reached similar conclusions to mine. The first, Mian and Sufi (2009), using data from a national consumer credit bureau over the years 1997 to 2008, reported that the debt-to-income ratio for U.S. households roughly doubled between 2002 and 2007. They also found that money extracted from increased home equity loans is not used to purchase new real estate or pay down credit card balances, but rather the borrowed funds are used for real expenditures (though they do not estimate whether the new debt expanded existing consumption or enhanced it). The second, Khandani, Lo, and Merton (2009), simulated the effect of the housing price decline from June 2006 to December 2008 and estimated a total loss of \$1.5 trillion in the U.S. housing market. They also found that a significant percentage of homeowners wound up with negative home equity.
} 
households with zero or negative net worth increased by 1.6 percentage points to reach its highest level over the years 1983 to 2007, though the percent with non-positive non-home wealth fell slightly.

Wealth inequality was up slightly from 2001 to 2004 and again from 2004 to 2007, while the inequality of non-home wealth was up sharply from 2001 to 2004, with the share of top 1 percent increasing by 2.5 percentage points after a marked decline from 1998 to 2001, and it was up again a bit from 2004 to 2007. Income inequality actually fell from 2000 to 2003, but then rose sharply from 2003 to 2006, for a net increase over the six years (an increase of 0.12 Gini points). The number of households worth $\$ 1,000,000$ or more, $\$ 5,000,000$ or more, and especially \$10,000,000 or more surged during the 1990s and once again from 2001 to 2007.

The mean wealth of the top 1 percent jumped to $\$ 18.5$ million in 2007. The percentage increase in net worth (also that of non-home wealth and income) from 1983 to 2007 was much greater for the top wealth (and income) groups than for those lower in the distribution. Moreover, the average wealth of the poorest 40 percent declined by 63 percent between 1983 and 2007 and, by 2007, had fallen to only $\$ 2,200$. All in all, the greatest gains in wealth and income were enjoyed by the upper 20 percent, particularly the top 1 percent, of the respective distributions. Between 1983 and 2007, the top 1 percent received 35 percent of the total growth in net worth, 43 percent of the total growth in non-home wealth, and 44 percent of the total increase in income. The figures for the top 20 percent are 89 percent, 94 percent, and 87 percent, respectively.

The biggest story for the early and mid-2000s is the sharply rising debt-to-income ratio, reaching its highest level in almost 25 years, at 119 percent in 2007. Also the debt-equity ratio (ratio of debt-to-net-worth) was way up, from 14.3 percent in 2001 to 18.1 percent in 2007. Most of the rising debt was from increased mortgages on homes. In contrast, during the late 1990s, indebtedness fell substantially and by 2001 the overall debt-equity ratio was lower than in 1983. The proportion of households reporting zero or negative net worth, after increasing from 15.5 percent in 1983 to 18 percent in 1998, fell to 17.6 percent in 2001, but then increased to 18.6 percent in 2007.

Another notable trend was the big increase in the value of homes as a share of total assets from 2001 to 2007 and the corresponding fall in the value of stocks held to total assets. As shown above, these two changes largely mirror relative price movements over the period, 
particularly from 2001 to 2004. Pension accounts as a share of total assets also fell off a bit from 2001 to 2007. Net equity in owner-occupied housing as a share of total assets fell sharply from 23.8 percent in 1983 to 18.2 percent in 1998 and then rebounded to 21.4 percent in 2007, reflecting rising mortgage debt on homeowner's property between 1983 and 1998, which grew from 21 to 37 percent, before retreating somewhat to 35 percent in 2007.

Evidence of the middle-class squeeze is that for the middle three wealth quintiles there was a huge increase in the debt-income ratio from 100 to 157 percent from 2001 to 2007 and an almost doubling of the debt-equity ratio from 31.7 to 61.1 percent. Moreover, total stocks as a share of total assets fell off from 12.6 to 7 percent for the middle class. The debt-equity ratio in 2007 was also much higher among the middle 60 percent of households (at 0.61) than among the top 1 percent $(0.028)$ or the next 19 percent $(0.121)$. Moreover, the evidence suggests that middle-class households, experiencing stagnating incomes, expanded their debt almost exclusively in order to finance normal consumption expenditures.

The percent of all households with a defined-contribution pension plan also fell from 52.2 to 49.7 from 2001 to 2004, but then recovered to 52.2 percent in 2007. For the middle class, there was a slight increase from 2001 to 2007. The overall stock ownership rate (either directly or indirectly through mutual funds, trust funds, or pension plans) also fell from 51.9 percent in 2001 to 49.1 percent in 2007. For the middle class, the fall was from 51.1 to 47.8 percent. There was also a pronounced decline in the share of middle-class households (and of all households) with $\$ 5,000$ or more of stocks and with $\$ 10,000$ or more of stocks.

The concentration of investment-type assets generally remained as high in 2007 as during the previous two decades. About 90 percent of the total value of stock shares, bonds, trusts, and business equity, and about 80 percent of non-home real estate were held by the top 10 percent of households. Stock ownership was also highly skewed by wealth and income class. The top 1 percent of households classified by wealth owned 38 percent of all stocks in 2007, the top 10 percent owned 81 percent, and the top quintile held 91 percent. Moreover, 84 percent of all stocks were owned by households earning $\$ 75,000$ or more and 92 percent by households with incomes of $\$ 50,000$ or more.

The racial disparity in wealth holdings, after stabilizing during most of the 1990s, widened in the years between 1998 and 2001 as the ratio of average net worth holdings dropped sharply from 0.18 to 0.14 and the ratio of median net worth from 0.12 to 0.10 . From 2001 to 
2007 the mean wealth gap narrowed again, with the ratio of mean wealth rising to 0.19 , but that of median wealth fell to 0.06 . The relative gains made by black households in the 2000s are ascribable to the fact that blacks have a higher share of homes and a lower share of stocks in their portfolio than do whites and to the fact that house prices rose relative to stock prices over the period.

Between 1998 and 2001, mean non-home wealth among white households also surged by 34 percent, but went up by only 6 percent among black households, so that the ratio dwindled from 0.15 to 0.12 - even lower than in 1983 . However, by 2007 the ratio had climbed back to 0.14. The black homeownership rate grew from 44.3 to 50.1 percent between 1983 and 2004, but then slipped to 48.6 percent in 2007; the homeownership rate relative to white households, after increasing from a ratio of 0.65 in 1983 to 0.67 in 1998, slipped back to 0.64 in 2001, but then recovered slightly to 0.65 in 2004.

Hispanic households also lost ground in absolute terms and relative to non-Hispanic white households in terms of both net worth and non-home wealth between 1998 and 2001, but then regained the ground in the 2000s. The homeownership rate among Hispanic households, after advancing from 33 percent in 1983 to 44 percent in 1995, leveled off in the ensuing six years, but then surged to 49 percent in 2007; the ratio of homeownership rates advanced from 48 percent in 1983 to 64 percent in 1995, dropped to 60 percent in 2001, but then climbed to 66 percent in 2007.

At least since 1989, wealth shifted in relative terms away from young households under age 55, particularly those under age 35, and toward households in age group 55 to 74 . A similar pattern is found for non-home wealth. The average net worth and non-home wealth of households in age group 75 and over also fell relative to the overall mean between 1989 and 2007.

I also updated the wealth figures to July 1, 2009 on the basis of changes in house and stock prices. My estimates indicate that while mean wealth (in 2007 dollars) fell by 17.3 percent between 2007 and 2009, median wealth plunged by 36.1 percent. The results show a fairly steep rise in wealth inequality, with the Gini coefficient swelling from 0.834 to 0.865 and the share of the top 1 percent advancing from 34.6 to 37.1 percent. I also estimate that 16.6 percent of homeowners were "underwater" with greater mortgage debt than the value of their homes. 


\section{REFERENCES}

Avery, Robert B., Gregory E. Elliehausen, and Arthur B. Kennickell. 1988. "Measuring Wealth with Survey Data: An Evaluation of the 1983 Survey of Consumer Finances." Review of Income and Wealth series 34(5): 339-369.

Blau, Francine D., and John W. Graham. 1990. "Black-White Differences in Wealth and Asset Composition.” Quarterly Journal of Economics 105(1): 321-339.

Board of Governors of the Federal Reserve System. 1998. "Flow of Funds Accounts of the United States: Flows and Outstanding Second Quarter 1998.” September 11.

Conley, Dalton. 1999. Being Black, Living in the Red: Race, Wealth and Social Policy in America. Berkeley and Los Angeles: University of California Press.

Gittleman, Maury, and Edward N. Wolff. 2004. "Racial Differences in Patterns of Wealth Accumulation.” Journal of Human Resources 39(1): 193-227.

Kennickell, Arthur B. 2001. "Modeling Wealth with Multiple Observations of Income: Redesign of the Sample for the 2001 Survey of Consumer Finances." October, available at: http://www.federalreserve.gov/pubs/oss/oss2/method.html.

Kennickell, Arthur B., Douglas A. McManus, and R. Louise Woodburn. 1996. "Weighting Design for the 1992 Survey of Consumer Finances.” Federal Reserve Board of Washington (March). Unpublished paper.

Kennickell, Arthur B., and R. Louise Woodburn. 1992. "Estimation of Household Net Worth Using Model-Based and Design-Based Weights: Evidence from the 1989 Survey of Consumer Finances.” Federal Reserve Board of Washington (April). Unpublished paper. . 1999. "Consistent Weight Design for the 1989, 1992, and 1995 SCFs, and the Distribution of Wealth.” Review of Income and Wealth series 45(2): 193-216.

Khandani, Amir E., Andrew W. Lo, and Robert C. Merton. 2009. "Systemic Risk and the Refinancing Ratchet Effect.” Working Paper No. 15362. Cambridge, MA: National Bureau of Economic Research (NBER).

Mian, Artif, and Amir Sufi. 2009. "House Prices, Home Equity-Based Borrowing, and the U.S. Household Leverage Crisis.” Working Paper No. 15283. Cambridge, MA: National Bureau of Economic Research (NBER).

Modigliani, Franco, and Richard Brumberg. 1954. "Utility Analysis and the Consumption Function: An Interpretation of Cross-Section Data.” in K. Kurihara (ed.), Post-Keynesian Economics. New Brunswick, NJ: Rutgers University Press. 
Oliver, Melvin L., and Thomas M. Shapiro. 1997. Black Wealth, White Wealth. New York: Routledge.

Spilerman, Seymour. 2000. "Wealth and Stratification Processes.” American Review of Sociology 26(a): 497-524.

U.S. Council of Economic Advisers. 2004. Economic Report of the President, 1994. Washington, DC: United States Government Printing Office.

Wolff, Edward N. 1987. "Estimates of Household Wealth Inequality in the United States, 196283.” Review of Income and Wealth series 33(3): 231-256.

. 1994. "Trends in Household Wealth in the United States, 1962-1983 and 19831989.” Review of Income and Wealth series 40(2): 143-174.

. 1996. TOP HEAVY: A Study of Increasing Inequality of Wealth in America. New York: New Press.

1998. "Recent Trends in the Size Distribution of Household Wealth.” Journal of Economic Perspectives 12(3): 131-150.

. 2001. "Recent Trends in Wealth Ownership, from 1983 to 1998.” in Thomas M. Shapiro and Edward N. Wolff (eds.), Assets for the Poor: The Benefits of Spreading Asset Ownership. New York: Russell Sage Press.

. 2002a. TOP HEAVY: A Study of Increasing Inequality of Wealth in America. Newly updated and expanded edition. New York: New Press.

. 2002b. Retirement Insecurity: The Income Shortfalls Awaiting the Soon-to-Retire. Washington, DC: Economic Policy Institute.

. 2007. "Recent Trends in Household Wealth in the United States: Rising Debt and the Middle-Class Squeeze.” Working Paper No. 502. Annandale-on-Hudson, NY: The Levy Economics Institute of Bard College. 


\section{APPENDIX A}

It should be noted at the outset that there appeared to be a substantial change in the sampling frame used in the 1992 survey in comparison to the 1989 survey. For consistency with the earlier results, I adjusted the weights used in the 1992 Survey of Consumer Finances.

The problem can be seen most easily in the following table:

\section{Comparison of SOI and SCF Size Distributions}

\begin{tabular}{|c|c|c|c|c|}
\hline \multirow{2}{*}{$\begin{array}{l}\text { Adjusted Gross } \\
\text { Income or House- } \\
\text { hold Income } \\
\text { [Current \$] }\end{array}$} & \multicolumn{2}{|c|}{$\begin{array}{l}\text { SCF Distribution: } \\
\text { Percentage of } \\
\text { All Households }\end{array}$} & \multicolumn{2}{|c|}{$\begin{array}{l}\text { SOI Distribution: } \\
\text { Percentage of } \\
\text { All Tax Returns }\end{array}$} \\
\hline & 1989 & 1992 & 1989 & 1992 \\
\hline Under \$100,000 & 95.7 & 94.9 & 97.4 & 96.7 \\
\hline$\$ 100,000-199,999$ & 3.107 & 3.948 & 1.864 & 2.474 \\
\hline$\$ 200,000-499,999$ & 0.895 & 0.892 & 0.546 & 0.657 \\
\hline \$500,000-999,999 & 0.187 & 0.182 & 0.103 & 0.124 \\
\hline$\$ 1,000,000$ or more & 0.073 & 0.040 & 0.051 & 0.059 \\
\hline \multicolumn{5}{|l|}{ Of Which: } \\
\hline$\$ 1,000,000-3,999,999$ & 0.0550 & 0.0293 & & \\
\hline$\$ 4,000,000-6,999,999$ & 0.0128 & 0.0021 & & \\
\hline$\$ 7,000,000$ or more & 0.0049 & 0.0002 & & \\
\hline Total & 100.0 & 100.0 & 100.0 & 100.0 \\
\hline
\end{tabular}

a. Source: Own computations from the 1989 and 1992 SCF.

b. Sources: "Selected Historical and Other Data," Statistics of Income Bulletin, Winter 1993-94, Vol. 13, No. 4, pp. 179-80; "Selected Historical and Other Data," Statistics of Income Bulletin, Winter 1994-95, Vol. 15, No. 3, pp. $180-81$.

A comparison of weights used in the 1989 and 1992 SCF shows a very sharp attenuation in the weights at the top of the income distribution. According to these figures, the percentage of households with incomes between $\$ 1,000,000$ and $\$ 4,000,000$ declined from 0.055 to 0.029 , or by almost half; the percentage in the income range $\$ 4,000,000$ to $\$ 7,000,000$ fell from 0.013 to 0.002, or by over 80 percent; and the percentage with incomes of $\$ 7,000,000$ or more decreased from 0.0049 to 0.0002 , or by over 95 percent. These changes are highly implausibleparticularly in light of results from the Current Population Survey or CPS (available on the 
internet), which show a slightly rising degree of income inequality over this period (the Gini coefficient increased from 0.427 to 0.428 ).

The table also compares the size distribution of income computed from the Internal Revenue Service Statistics of Income (SOI) in 1989 and 1992 with that from the two SCF files. The SOI figures are based on actual tax returns filed in the two years. There are three major differences between the two data sources. First, the SOI data use the tax return as the unit of observation, whereas the SCF figures are based on the household unit. Second, individuals who do not file tax returns are excluded from the SOI tabulations. Third, the size distribution for the SOI data is based on adjusted gross income (AGI), whereas the SCF distributions are based on total household income.

Despite the differences in concept and measurement, trends in the size distribution of AGI can give a rough approximation to actual changes in the size distribution of household (Census) income. What is most striking is that the SOI figures show a slight increase in the percent of units in income class $\$ 1,000,000$ and more, from 0.051 in 1989 to 0.059 percent in 1992, whereas the SCF figures show a sharp decline, from 0.073 to 0.040 percent.

Results from the SOI data fail to provide any independent corroboration for the sharp decline in the number of households with incomes of $\$ 1,000,000$ or more between 1989 and 1992. Accordingly, I adjusted the 1992 weights to conform to the 1989 weighting scheme. The adjustment factors for the 1992 weights are given by the inverse of the normalized ratio of weights between 1992 and 1989, shown in the last column of the preceding table:

\begin{tabular}{|c|c|}
\hline $\begin{array}{l}\text { Income in } \\
1989 \text { Dollars }\end{array}$ & $\begin{array}{l}\text { Adjustment } \\
\text { Factors for } \\
1992 \text { Weights }\end{array}$ \\
\hline Under \$200,000 & 0.992 \\
\hline$\$ 200,000-999,999$ & 1.459 \\
\hline$\$ 1,000,000-3,999,999$ & 1.877 \\
\hline$\$ 4,000,000-6,999,999$ & $9 \quad 4.844$ \\
\hline$\$ 7,000,000$ or more & 12.258 \\
\hline
\end{tabular}


The resulting size distribution of income for 1989 and 1992 is as follows:

\begin{tabular}{|c|c|c|}
\hline $\begin{array}{l}\text { Income } \\
\text { Shares } \\
\text { (in percent) }\end{array}$ & $\begin{array}{l}989 \text { SCF } \\
\text { Using } \\
\text { Original } \\
\text { Weights }\end{array}$ & $\begin{array}{c}1992 \text { SCF } \\
\text { Using } \\
\text { Adjusted } \\
\text { Weights }\end{array}$ \\
\hline Share of the Top $1 \%$ & 16.4 & 15.7 \\
\hline Share of the Top 5\% & 29.7 & 30.5 \\
\hline Share of the Top $10 \%$ & 40.1 & 41.1 \\
\hline Share of the Top $20 \%$ & 55.3 & 56.4 \\
\hline Gini Coefficient: & 0.521 & 0.528 \\
\hline
\end{tabular}

The calculations show a slight increase in overall income inequality, as measured by the Gini coefficient, a result that is consistent with both the SOI and the CPS data. 


\section{APPENDIX B: Tables and Figures}

\begin{tabular}{|c|c|c|c|c|c|c|c|c|c|c|c|c|}
\hline \multicolumn{9}{|c|}{$\begin{array}{l}\text { Table 1. Mean and Median Wealth and Income, 1983-2007 } \\
\text { (in thousands, } 2007 \text { dollars) }\end{array}$} & \multicolumn{4}{|c|}{ Percentage Change } \\
\hline & 1983 & 1989 & 1992 & 1995 & 1998 & 2001 & 2004 & 2007 & $\begin{array}{l}1983- \\
1989\end{array}$ & $\begin{array}{l}1989- \\
2001\end{array}$ & $\begin{array}{l}2001- \\
2007\end{array}$ & $\begin{array}{l}1983- \\
2007\end{array}$ \\
\hline \multicolumn{13}{|l|}{ A. Net Worth } \\
\hline$\overline{\text { 1. Median }}$ & 69.5 & 74.3 & 63.4 & 62.1 & 77.2 & 86.1 & 85.5 & 102.5 & 7.0 & 15.8 & 19.1 & 47.5 \\
\hline 2. Mean & 270.4 & 309.8 & 301.2 & 278.3 & 343.8 & 445.1 & 472.5 & 536.1 & 14.6 & 43.7 & 20.4 & 98.2 \\
\hline \multicolumn{13}{|l|}{ 3. Percent with net worth } \\
\hline a. Zero or negative & 15.5 & 17.9 & 18.0 & 18.5 & 18.0 & 17.6 & 17.0 & 18.6 & & & & \\
\hline b. Less than $\$ 5,000^{a}$ & 25.4 & 27.6 & 27.2 & 27.8 & 27.2 & 26.6 & 26.8 & 26.6 & & & & \\
\hline c. Less than $\$ 10,000^{a}$ & 29.7 & 31.8 & 31.2 & 31.9 & 30.3 & 30.1 & 29.9 & 30.0 & & & & \\
\hline \multicolumn{13}{|l|}{ B. Non-home Wealth } \\
\hline 1. Median & 15.0 & 17.7 & 14.9 & 13.5 & 22.7 & 27.2 & 20.0 & 23.5 & 18.0 & 53.4 & -13.5 & 56.7 \\
\hline 2. Mean & 196.2 & 231.3 & 229.6 & 213.5 & 270.0 & 349.5 & 350.5 & 400.9 & 17.8 & 51.1 & 14.7 & 104.3 \\
\hline $\begin{array}{l}\text { 3. Percent with zero } \\
\text { or negative non-home wealth }\end{array}$ & 25.7 & 26.8 & 28.2 & 28.7 & 25.7 & 25.5 & 28.0 & 27.4 & & & & \\
\hline \multicolumn{13}{|l|}{ C. Income ${ }^{b}$} \\
\hline 1. Median & 43.5 & 48.3 & 45.3 & 46.4 & 49.5 & 49.4 & 48.7 & 50.2 & 11.2 & 2.3 & 1.6 & 15.5 \\
\hline 2. Mean & 52.9 & 61.1 & 57.4 & 61.1 & 66.0 & 68.1 & 66.4 & 67.6 & 15.5 & 11.6 & -0.8 & 27.9 \\
\hline \multicolumn{13}{|c|}{$\begin{array}{l}\text { Source: Own computations from the } 1983,1989,1992,1995,1998,2001,2004 \text {, and } 2007 \text { Survey of Consumer Finances. } \\
\text { The } 1983 \text { weights are the Full Sample } 1983 \text { Composite Weights; the } 1989 \text { weights are the average of the } \\
\text { SRC-Design-S1 series (X40131) and the SRC design-based weights (X40125). The } 1992 \text { calculations are } \\
\text { based on the design-based weights (X42000), with my adjustments (see Wolff [1996]). The } 1995 \text { weights are } \\
\text { the design-based weights (X42000). The 1998, 2001, and } 2004 \text { weights are partially design-based weights } \\
\text { (X42001), which account for the systematic deviations from CPS estimates of homeownership by racial/ethnic } \\
\text { groups. The 1983, 1989, 1992, and } 1995 \text { asset and liability entries are aligned to national balance sheet totals. } \\
\text { The } 1998,2001 \text {, and } 2004 \text { asset and liability entries are based on original, unadjusted survey data. Figures are deflated using the CPI-U. } \\
\text { a. Constant } 1995 \text { dollars. } \\
\text { b. Source for household income data see the U.S. Census of the Bureau and Current Populations Surveys (available on the internet). }\end{array}$} \\
\hline
\end{tabular}




\begin{tabular}{|c|c|c|c|c|c|c|c|c|c|c|}
\hline \multirow[b]{2}{*}{ Year } & \multirow[b]{2}{*}{$\begin{array}{c}\text { Gini } \\
\text { Coefficient }\end{array}$} & \multicolumn{9}{|c|}{ Percentage Share of Wealth or Income Held by: } \\
\hline & & $\begin{array}{l}\text { Top } \\
1.0 \%\end{array}$ & $\begin{array}{l}\text { Next } \\
4.0 \%\end{array}$ & $\begin{array}{l}\text { Next } \\
5.0 \%\end{array}$ & $\begin{array}{c}\text { Next } \\
10.0 \%\end{array}$ & $\begin{array}{c}\text { Top } \\
20.0 \%\end{array}$ & $\begin{array}{c}\text { 4th } \\
20.0 \%\end{array}$ & $\begin{array}{c}\text { 3rd } \\
20.0 \%\end{array}$ & $\begin{array}{r}\text { Bottom } \\
40.0 \%\end{array}$ & All \\
\hline \multicolumn{11}{|c|}{ A. Net Worth } \\
\hline 1983 & 0.799 & 33.8 & 22.3 & 12.1 & 13.1 & 81.3 & 12.6 & 5.2 & 0.9 & 100.0 \\
\hline 1989 & 0.832 & 37.4 & 21.6 & 11.6 & 13.0 & 83.5 & 12.3 & 4.8 & -0.7 & 100.0 \\
\hline 1992 & 0.823 & 37.2 & 22.8 & 11.8 & 12.0 & 83.8 & 11.5 & 4.4 & 0.4 & 100.0 \\
\hline 1995 & 0.828 & 38.5 & 21.8 & 11.5 & 12.1 & 83.9 & 11.4 & 4.5 & 0.2 & 100.0 \\
\hline 1998 & 0.822 & 38.1 & 21.3 & 11.5 & 12.5 & 83.4 & 11.9 & 4.5 & 0.2 & 100.0 \\
\hline 2001 & 0.826 & 33.4 & 25.8 & 12.3 & 12.9 & 84.4 & 11.3 & 3.9 & 0.3 & 100.0 \\
\hline 2004 & 0.829 & 34.3 & 24.6 & 12.3 & 13.4 & 84.7 & 11.3 & 3.8 & 0.2 & 100.0 \\
\hline 2007 & 0.834 & 34.6 & 27.3 & 11.2 & 12.0 & 85.0 & 10.9 & 4.0 & 0.2 & 100.0 \\
\hline \multicolumn{11}{|c|}{ B. Non-home Wealth } \\
\hline 1983 & 0.893 & 42.9 & 25.1 & 12.3 & 11.0 & 91.3 & 7.9 & 1.7 & -0.9 & 100.0 \\
\hline 1989 & 0.926 & 46.9 & 23.9 & 11.6 & 11.0 & 93.4 & 7.4 & 1.7 & -2.5 & 100.0 \\
\hline 1992 & 0.903 & 45.6 & 25.0 & 11.5 & 10.2 & 92.3 & 7.3 & 1.5 & -1.1 & 100.0 \\
\hline 1995 & 0.914 & 47.2 & 24.6 & 11.2 & 10.1 & 93.0 & 6.9 & 1.4 & -1.3 & 100.0 \\
\hline 1998 & 0.893 & 47.3 & 21.0 & 11.4 & 11.2 & 90.9 & 8.3 & 1.9 & -1.1 & 100.0 \\
\hline 2001 & 0.888 & 39.7 & 27.8 & 12.3 & 11.4 & 91.3 & 7.8 & 1.7 & -0.7 & 100.0 \\
\hline 2004 & 0.902 & 42.2 & 26.7 & 12.0 & 11.6 & 92.5 & 7.3 & 1.2 & -1.1 & 100.0 \\
\hline 2007 & 0.908 & 42.7 & 29.3 & 10.9 & 10.1 & 93.0 & 6.8 & 1.3 & -1.0 & 100.0 \\
\hline \multicolumn{11}{|c|}{ C. Income (SCF) } \\
\hline 1982 & 0.480 & 12.8 & 13.3 & 10.3 & 15.5 & 51.9 & 21.6 & 14.2 & 12.3 & 100.0 \\
\hline 1988 & 0.521 & 16.6 & 13.3 & 10.4 & 15.2 & 55.6 & 20.6 & 13.2 & 10.7 & 100.0 \\
\hline 1991 & 0.528 & 15.7 & 14.8 & 10.6 & 15.3 & 56.4 & 20.4 & 12.8 & 10.5 & 100.0 \\
\hline 1994 & 0.518 & 14.4 & 14.5 & 10.4 & 15.9 & 55.1 & 20.6 & 13.6 & 10.7 & 100.0 \\
\hline 1997 & 0.531 & 16.6 & 14.4 & 10.2 & 15.0 & 56.2 & 20.5 & 12.8 & 10.5 & 100.0 \\
\hline 2000 & 0.562 & 20.0 & 15.2 & 10.0 & 13.5 & 58.6 & 19.0 & 12.3 & 10.1 & 100.0 \\
\hline 2003 & 0.540 & 17.0 & 15.0 & 10.9 & 14.9 & 57.9 & 19.9 & 12.1 & 10.2 & 100.0 \\
\hline 2006 & 0.574 & 21.3 & 15.9 & 9.9 & 14.3 & 61.4 & 17.8 & 11.1 & 9.6 & 100.0 \\
\hline
\end{tabular}




\begin{tabular}{|c|c|c|c|c|}
\hline \multicolumn{5}{|c|}{ Table 3. The Count of Millionaires and Multimillionaires, 1983-2007 } \\
\hline \multirow[b]{2}{*}{ Year } & \multirow{2}{*}{$\begin{array}{c}\text { Total } \\
\text { Number of } \\
\text { Households } \\
(\mathbf{1 , 0 0 0 s})\end{array}$} & \multicolumn{3}{|c|}{$\begin{array}{l}\text { Number of Households (in thousands) with } \\
\text { Net Worth Equal to or Exceeding (in 1995\$) }\end{array}$} \\
\hline & & 1 Million & 5 Million & 10 Million \\
\hline 1983 & 83,893 & 2,411 & 247.0 & 66.5 \\
\hline 1989 & 93,009 & 3,024 & 296.6 & 64.9 \\
\hline 1992 & 95,462 & 3,104 & 277.4 & 41.6 \\
\hline 1995 & 99,101 & 3,015 & 474.1 & 190.4 \\
\hline 1998 & 102,547 & 4,783 & 755.5 & 239.4 \\
\hline 2001 & 106,494 & 5,892 & $1,067.8$ & 338.4 \\
\hline 2004 & 112,107 & 6,466 & $1,120.0$ & 344.8 \\
\hline 2007 & 116,120 & 7,274 & $1,466.8$ & 464.2 \\
\hline \% Change & 38.4 & 201.7 & 493.8 & 598.3 \\
\hline
\end{tabular}




\begin{tabular}{|c|c|c|c|c|c|c|c|c|c|}
\hline Variable & $\begin{array}{r}\text { Top } \\
1.0 \% \\
\end{array}$ & $\begin{array}{r}\text { Next } \\
4.0 \% \\
\end{array}$ & $\begin{array}{r}\text { Next } \\
5.0 \% \\
\end{array}$ & $\begin{array}{r}\text { Next } \\
10.0 \% \\
\end{array}$ & $\begin{array}{r}\text { Top } \\
20.0 \% \\
\end{array}$ & $\begin{array}{r}\text { 4th } \\
20.0 \% \\
\end{array}$ & $\begin{array}{r}\text { 3rd } \\
20.0 \% \\
\end{array}$ & $\begin{array}{r}\text { Bottom } \\
40.0 \% \\
\end{array}$ & All \\
\hline \multicolumn{10}{|c|}{ A. Net Worth } \\
\hline 1983 & $9,127.0$ & $1,510.0$ & 656.6 & 354.5 & $1,099.7$ & 170.0 & 70.6 & 5.9 & 270.4 \\
\hline 2007 & $18,529.0$ & $3,656.0$ & $1,201.3$ & 641.9 & $2,278.9$ & 291.0 & 106.0 & 2.2 & 536.1 \\
\hline$\%$ change & 103.0 & 142.2 & 83.0 & 81.1 & 107.2 & 71.2 & 50.1 & -62.9 & 98.2 \\
\hline$\%$ of gain ${ }^{a}$ & 35.4 & 32.3 & 10.3 & 10.8 & 88.8 & 9.1 & 2.7 & -0.6 & 100.0 \\
\hline \multicolumn{10}{|c|}{ B. Non-home Wealth } \\
\hline 1983 & $7,870.0$ & $1,152.0$ & 450.3 & 201.8 & 837.4 & 72.5 & 15.6 & -4.0 & 183.5 \\
\hline 2007 & $17,116.0$ & $2,936.0$ & 874.4 & 404.1 & $1,863.6$ & 135.7 & 26.0 & -10.5 & 400.9 \\
\hline$\%$ change & 117.5 & 154.8 & 94.2 & 100.2 & 122.5 & 87.3 & 66.6 & 159.6 & 118.5 \\
\hline$\%$ of gain ${ }^{a}$ & 42.5 & 32.8 & 9.8 & 9.3 & 94.4 & 5.8 & 1.0 & -1.2 & 100.0 \\
\hline \multicolumn{10}{|l|}{ C. Income } \\
\hline 1982 & 786.4 & 203.2 & 126.2 & 94.7 & 158.8 & 66.3 & 43.3 & 18.9 & 61.2 \\
\hline 2006 & $1,786.8$ & 334.4 & 166.5 & 120.0 & 257.9 & 74.7 & 46.7 & 20.2 & 83.9 \\
\hline$\%$ change & 127.2 & 64.6 & 32.0 & 26.7 & 62.3 & 12.7 & 7.7 & 7.1 & 37.1 \\
\hline$\%$ of gain ${ }^{\mathrm{a}}$ & 44.1 & 23.1 & 8.9 & 11.2 & 87.3 & 7.4 & 2.9 & 2.4 & 100.0 \\
\hline \multicolumn{10}{|c|}{$\begin{array}{l}\text { Source: Own computations from the } 1983 \text { and } 2007 \text { Survey of Consumer Finances. } \\
\text { For the computation of percentile shares of net worth, households are ranked according to their net worth; } \\
\text { for percentile shares of non-home wealth, households are ranked according to their non-home wealth; and } \\
\text { for percentile shares of income, households are ranked according to their income. } \\
\text { a. The computation is performed by dividing the total increase in wealth of a given group by the total increase of } \\
\text { wealth for all households over the period, under the assumption that the number of households in each group } \\
\text { remains unchanged over the period. It should be noted that the households found in a given group (such as } \\
\text { the top quintile) may be different in each year. }\end{array}$} \\
\hline
\end{tabular}




\begin{tabular}{|c|c|c|c|c|c|c|c|c|}
\hline \multicolumn{9}{|c|}{$\begin{array}{l}\text { Table 5. Composition of Total Household Wealth, 1983-2007 } \\
\text { (percent of gross assets) }\end{array}$} \\
\hline Wealth Component & 1983 & 1989 & 1992 & 1995 & 1998 & 2001 & 2004 & 2007 \\
\hline Principal residence (gross value) & 30.1 & 30.2 & 29.8 & 30.4 & 29.0 & 28.2 & 33.5 & 32.8 \\
\hline Other real estate (gross value) ${ }^{\mathrm{a}}$ & 14.9 & 14.0 & 14.7 & 11.0 & 10.0 & 9.8 & 11.5 & 11.3 \\
\hline Unincorporated business equity ${ }^{b}$ & 18.8 & 17.2 & 17.7 & 17.9 & 17.7 & 17.2 & 17.1 & 20.1 \\
\hline Liquid assets ${ }^{c}$ & 17.4 & 17.5 & 12.2 & 10.0 & 9.6 & 8.8 & 7.3 & 6.6 \\
\hline Pension accounts $^{d}$ & 1.5 & 2.9 & 7.2 & 9.0 & 11.6 & 12.3 & 11.8 & 12.1 \\
\hline Financial securities ${ }^{\mathrm{e}}$ & 4.2 & 3.4 & 5.1 & 3.8 & 1.8 & 2.3 & 2.1 & 1.5 \\
\hline Corporate stock and mutual funds & 9.0 & 6.9 & 8.1 & 11.9 & 14.8 & 14.8 & 11.9 & 11.8 \\
\hline Net equity in personal trusts & 2.6 & 3.1 & 2.7 & 3.2 & 3.8 & 4.8 & 2.9 & 2.3 \\
\hline Miscellaneous assets $^{\mathrm{f}}$ & 1.3 & 4.9 & 2.5 & 2.8 & 1.8 & 1.8 & 1.8 & 1.7 \\
\hline Total & 100.0 & 100.0 & 100.0 & 100.0 & 100.0 & 100.0 & 100.0 & 100.0 \\
\hline Debt on principal residence & 6.3 & 8.6 & 9.8 & 11.0 & 10.7 & 9.4 & 11.6 & 11.4 \\
\hline All other debt ${ }^{g}$ & 6.8 & 6.4 & 6.0 & 5.3 & 4.2 & 3.1 & 3.9 & 3.9 \\
\hline$\underline{\text { Total debt }}$ & 13.1 & 15.0 & 15.7 & 16.3 & 15.0 & 12.5 & 15.5 & 15.3 \\
\hline \multicolumn{9}{|l|}{ Memo (selected ratios in percent) } \\
\hline Debt/equity ratio & 15.1 & 17.6 & 18.7 & 19.4 & 17.6 & 14.3 & 18.4 & 18.1 \\
\hline Debt/income ratio & 68.4 & 87.6 & 88.8 & 91.3 & 90.9 & 81.1 & 115.0 & 118.7 \\
\hline Net home equity/total assets ${ }^{\text {h }}$ & 23.8 & 21.6 & 20.1 & 19.5 & 18.2 & 18.8 & 21.8 & 21.4 \\
\hline Principal residence debt/house value & 20.9 & 28.6 & 32.7 & 36.0 & 37.0 & 33.4 & 34.8 & 34.9 \\
\hline $\begin{array}{l}\text { Stocks, directly or indirectly owned/ } \\
\text { total assets }{ }^{i}\end{array}$ & 11.3 & 10.2 & 13.7 & 16.8 & 22.6 & 24.5 & 17.5 & 16.8 \\
\hline \multicolumn{9}{|c|}{$\begin{array}{l}\text { Source: Own computations from the } 1983,1989,1992,1995,1998,2001,2004 \text {, and } 2007 \text { SCF. } \\
\text { a. In } 2001,2004 \text {, and } 2007 \text {, this equals the gross value of other residential real estate plus the net equity in } \\
\text { nonresidential real estate. }\end{array}$} \\
\hline \multicolumn{9}{|c|}{ b. Net equity in unincorporated farm and nonfarm businesses and closely-held corporations. } \\
\hline \multicolumn{9}{|c|}{$\begin{array}{l}\text { c. Checking accounts, savings accounts, time deposits, money-market funds, certificates of deposits, and the } \\
\text { cash surrender value of life insurance. }\end{array}$} \\
\hline \multicolumn{9}{|c|}{$\begin{array}{l}\text { d. IRAs, Keogh plans, } 401(\mathrm{k}) \text { plans, the accumulated value of defined contribution pension plans, and other } \\
\text { retirement accounts. }\end{array}$} \\
\hline \multicolumn{9}{|c|}{ e. Corporate bonds, government bonds (including savings bonds), open-market paper, and notes. } \\
\hline \multicolumn{9}{|c|}{ f. Gold and other precious metals, royalties, jewelry, antiques, furs, loans to friends and } \\
\hline \multicolumn{9}{|c|}{$\begin{array}{l}\text { relatives, future contracts, and miscellaneous assets. } \\
\text { g. Mortgage debt on all real property except principal residence, as well as credit card, installment, and other } \\
\text { consumer debt. }\end{array}$} \\
\hline $\begin{array}{l}\text { h. Ratio of gross value of principal res } \\
\text { i. Includes direct ownership of stock s } \\
\text { Keogh plans, } 401(\mathrm{k}) \text { plans, and other } 1\end{array}$ & $\begin{array}{l}\text { less mor } \\
\text { ad indir } \\
\text { ent acco }\end{array}$ & $\begin{array}{l}\text { age deb } \\
\text { owners } \\
\text { ts. }\end{array}$ & $\begin{array}{l}\text { p princ } \\
\text { p throu }\end{array}$ & $\begin{array}{l}\text { reside } \\
\text { mutual }\end{array}$ & $\begin{array}{l}\text { e to tot } \\
\text { inds, tr }\end{array}$ & Ists, IR & & \\
\hline
\end{tabular}




\begin{tabular}{|c|c|c|c|c|}
\hline Asset & $\begin{array}{c}\text { All } \\
\text { Households } \\
\end{array}$ & $\begin{array}{c}\text { Top } \\
1 \text { Percent }\end{array}$ & $\begin{array}{c}\text { Next } \\
19 \text { Percent }\end{array}$ & $\begin{array}{c}\text { Middle } \\
3 \text { Quintiles }\end{array}$ \\
\hline Principal residence & 32.8 & 10.2 & 31.8 & 65.1 \\
\hline $\begin{array}{l}\text { Liquid assets (bank deposits, money } \\
\text { market funds, and cash surrender } \\
\text { value of life insurance) }\end{array}$ & 6.6 & 4.5 & 7.3 & 7.8 \\
\hline Pension accounts & 12.1 & 5.8 & 15.9 & 12.9 \\
\hline $\begin{array}{l}\text { Corporate stock, financial securities, } \\
\text { mutual funds, and personal trusts }\end{array}$ & 15.5 & 25.2 & 15.0 & 3.6 \\
\hline $\begin{array}{l}\text { Unincorporated business equity and } \\
\text { other real estate }\end{array}$ & 31.3 & 52.3 & 28.5 & 9.3 \\
\hline Miscellaneous assets & 1.7 & 2.0 & 1.6 & 1.3 \\
\hline Total assets & 100.0 & 100.0 & 100.0 & 100.0 \\
\hline \multicolumn{5}{|l|}{ Memo (selected ratios in percent) } \\
\hline$\overline{\text { Debt/equity ratio }}$ & 18.1 & 2.8 & 12.1 & 61.1 \\
\hline Debt/income ratio & 118.7 & 39.4 & 109.8 & 156.7 \\
\hline Net home equity/total assets ${ }^{\text {a }}$ & 21.4 & 8.7 & 23.6 & 34.8 \\
\hline Principal residence debt/house value & 34.9 & 15.2 & 25.6 & 46.6 \\
\hline All stocks/total assets ${ }^{\mathbf{b}}$ & 16.8 & 21.4 & 18.6 & 7.0 \\
\hline \multicolumn{5}{|l|}{ Ownership Rates (percent) } \\
\hline $\begin{array}{l}\text { Principal residence } \\
\end{array}$ & 68.6 & 98.8 & 96.0 & 76.9 \\
\hline Mobile home & 4.1 & $\mathbf{0 . 0}$ & 0.3 & 6.0 \\
\hline Other real estate & 19.0 & 76.0 & 48.0 & 14.7 \\
\hline Vacation homes & 6.5 & 37.4 & 16.7 & 4.9 \\
\hline Pension assets & 52.6 & 87.7 & 81.1 & 53.4 \\
\hline Unincorporated business & 12.0 & 73.8 & 29.7 & 8.8 \\
\hline $\begin{array}{l}\text { Corporate stock, financial securities, } \\
\text { mutual funds, and personal trusts }\end{array}$ & 27.8 & 85.3 & 63.4 & 23.1 \\
\hline Stocks, directly or indirectly owned & 49.1 & 92.6 & 85.5 & 47.8 \\
\hline (1) $\$ 5,000$ or more & 36.3 & 89.7 & 82.2 & 31.8 \\
\hline (2) $\$ 10,000$ or more & 31.6 & 89.1 & 78.4 & 26.0 \\
\hline \multicolumn{5}{|c|}{$\begin{array}{l}\text { Source: Own computations from the } 2007 \text { SCF. Households are classified into wealth class } \\
\text { according to their net worth. Brackets for } 2007 \text { are: }\end{array}$} \\
\hline $\begin{array}{l}\text { Top } 1 \text { percent: Net worth of } \$ 8,232, \\
\text { Next } 19 \text { percent: Net worth between } \\
\text { Quintiles } 2 \text { through 4: Net worth bet }\end{array}$ & $\begin{array}{l}\text { or more } \\
3,000 \text { and } \$ 8 \text {, } \\
\text { n } \$ 200 \text { and } \$\end{array}$ & 2,000 & & \\
\hline \multicolumn{5}{|c|}{$\begin{array}{l}\text { Also, see notes to table } 5 \text {. } \\
\text { a. Ratio of gross value of principal residence less mortgage debt on principal residence to total } \\
\text { assets. } \\
\text { b. Includes direct ownership of stock shares and indirect ownership through mutual funds, } \\
\text { trusts, IRAs, Keogh plans, } 401(\mathrm{k}) \text { plans, and other retirement accounts. } \\
\text { c. Financial securities exclude U.S. government savings bonds in this tabulation. }\end{array}$} \\
\hline
\end{tabular}




\begin{tabular}{|c|c|c|c|c|c|c|}
\hline \multirow[b]{2}{*}{ Component } & \multicolumn{2}{|c|}{ Top 1 Percent } & \multicolumn{2}{|c|}{ Next 19 Percent } & \multicolumn{2}{|c|}{ Middle 3 Quintiles } \\
\hline & 1983 & 2007 & 1983 & 2007 & 1983 & 2007 \\
\hline Principal residence & 8.1 & 10.2 & 29.1 & 31.8 & 61.6 & 65.1 \\
\hline $\begin{array}{l}\text { Liquid assets (bank deposits, money } \\
\text { market funds, and cash surrender } \\
\text { value of life insurance) }\end{array}$ & 8.5 & 4.5 & 21.4 & 7.3 & 21.4 & 7.8 \\
\hline Pension accounts & 0.9 & 5.8 & 2.0 & 15.9 & 1.2 & 12.9 \\
\hline $\begin{array}{l}\text { Corporate stock, financial securities, } \\
\text { mutual funds, and personal trusts }\end{array}$ & 29.5 & 25.2 & 13.0 & 15.0 & 3.1 & 3.6 \\
\hline $\begin{array}{l}\text { Unincorporated business equity and } \\
\text { other real estate }\end{array}$ & 52.0 & 52.3 & 32.8 & 28.5 & 11.4 & 9.3 \\
\hline Miscellaneous assets & 1.0 & 2.0 & 1.6 & 1.6 & 1.3 & 1.3 \\
\hline Total assets & 100.0 & 100.0 & 100.0 & 100.0 & 100.0 & 100.0 \\
\hline \multicolumn{7}{|l|}{ Memo } \\
\hline Debt/equity ratio & 5.9 & 2.8 & 10.9 & 12.1 & 37.4 & 61.1 \\
\hline Debt/income ratio & 86.8 & 39.4 & 72.8 & 109.8 & 66.9 & 156.7 \\
\hline
\end{tabular}

Note: Own computations from the 1983 and 2007 Survey of Consumer Finances. Also, see notes to table 5. 


\begin{tabular}{|c|c|c|c|c|c|c|}
\hline \multicolumn{7}{|c|}{$\begin{array}{l}\text { Table 8. Composition of Household Wealth of the Middle Three Wealth Quintiles, 1983-2007 } \\
\text { (percent of gross assets) }\end{array}$} \\
\hline Asset & 1983 & 1989 & 1998 & 2001 & 2004 & 2007 \\
\hline Principal residence & 61.6 & 61.7 & 59.8 & 59.2 & 66.1 & 65.1 \\
\hline $\begin{array}{l}\text { Liquid assets (bank deposits, money } \\
\text { market funds, and cash surrender } \\
\text { value of life insurance) }\end{array}$ & 21.4 & 18.6 & 11.8 & 12.1 & 8.5 & 7.8 \\
\hline Pension accounts & 1.2 & 3.8 & 12.3 & 12.7 & 12.0 & 12.9 \\
\hline $\begin{array}{l}\text { Corporate stock, financial securities, } \\
\text { mutual funds, and personal trusts }\end{array}$ & 3.1 & 3.5 & 5.5 & 6.2 & 4.2 & 3.6 \\
\hline $\begin{array}{l}\text { Unincorporated business equity and } \\
\text { other real estate }\end{array}$ & 11.4 & 9.4 & 8.8 & 8.5 & 7.9 & 9.3 \\
\hline Miscellaneous assets & 1.3 & 2.9 & 1.8 & 1.2 & 1.4 & 1.3 \\
\hline Total assets & 100.0 & 100.0 & 100.0 & 100.0 & 100.0 & 100.0 \\
\hline \multicolumn{7}{|l|}{ Memo (selected ratios in percent) } \\
\hline Debt/equity ratio & 37.4 & 41.7 & 51.3 & 46.4 & 61.6 & 61.1 \\
\hline Debt/income ratio & 66.9 & 83.0 & 101.6 & 100.3 & 141.2 & 156.7 \\
\hline Net home equity/total assets ${ }^{\mathrm{a}}$ & 43.8 & 39.2 & 33.3 & 33.8 & 34.7 & 34.8 \\
\hline Principal residence debt/house value & 28.8 & 36.5 & 44.4 & 42.9 & 47.6 & 46.6 \\
\hline All stocks/total assets ${ }^{\mathrm{b}}$ & 2.4 & 3.3 & 11.2 & 12.6 & 7.5 & 7.0 \\
\hline \multicolumn{7}{|l|}{ Ownership Rates (percent) } \\
\hline Principal residence & 71.6 & 71.5 & 73.3 & 75.9 & 78.2 & 76.9 \\
\hline Other real estate & 15.4 & 15.5 & 13.7 & 13.2 & 13.6 & 14.7 \\
\hline Pension assets & 12.2 & 27.3 & 48.5 & 52.9 & 51.4 & 53.4 \\
\hline Unincorporated business & 8.5 & 8.4 & 8.5 & 7.9 & 8.1 & 8.8 \\
\hline $\begin{array}{l}\text { Corporate stock, financial securities, }{ }^{c} \\
\text { mutual funds, and personal trusts }\end{array}$ & 21.6 & 24.2 & 26.7 & 27.5 & 27.1 & 23.1 \\
\hline \multicolumn{7}{|c|}{$\begin{array}{l}\text { Source: Own computations from the Survey of Consumer Finances. Households are } \\
\text { classified into wealth class according to their net worth. Also, see notes to table } 5 \text {. } \\
\text { a. Ratio of gross value of principal residence less mortgage debt on principal residence to total assets. } \\
\text { b. Includes direct ownership of stock shares and indirect ownership through mutual funds, } \\
\text { trusts, IRAs, Keogh plans, } 401(\mathrm{k}) \text { plans, and other retirement accounts. } \\
\text { c. Financial securities exclude U.S. government savings bonds in this tabulation. }\end{array}$} \\
\hline
\end{tabular}




\begin{tabular}{|c|c|c|c|c|c|c|c|c|c|c|c|c|}
\hline \multicolumn{13}{|c|}{ Table 9. The Percent of Total Assets Held by Wealth Class, 2007} \\
\hline \multirow[b]{2}{*}{ Asset Type } & \multirow{2}{*}{$\begin{array}{c}\text { Top } \\
1.0 \% \\
\end{array}$} & \multirow{2}{*}{$\begin{array}{l}\text { Next } \\
9.0 \%\end{array}$} & \multirow{2}{*}{$\begin{array}{l}\text { Bottom } \\
90.0 \%\end{array}$} & \multirow[b]{2}{*}{ All } & \multicolumn{5}{|c|}{ Share of Top $10 \%$} & \multirow[b]{2}{*}{2001} & \multirow[b]{2}{*}{2004} & \multirow[b]{2}{*}{2007} \\
\hline & & & & & 1983 & 1989 & 1992 & 1995 & 1998 & & & \\
\hline \multicolumn{13}{|l|}{ A. Investment Assets } \\
\hline Stocks and mutual funds & 49.3 & 40.1 & 10.6 & 100.0 & 90.4 & 86.0 & 86.3 & 88.4 & 85.1 & 84.5 & 85.4 & 89.4 \\
\hline Financial securities & 60.6 & 37.9 & 1.5 & 100.0 & 82.9 & 87.1 & 91.3 & 89.8 & 84.1 & 88.7 & 87.9 & 98.5 \\
\hline Trusts & 38.9 & 40.5 & 20.6 & 100.0 & 95.4 & 87.9 & 87.9 & 88.5 & 90.8 & 86.7 & 81.5 & 79.4 \\
\hline Business equity & 62.4 & 30.9 & 6.7 & 100.0 & 89.9 & 89.8 & 91.0 & 91.7 & 91.7 & 89.6 & 90.3 & 93.3 \\
\hline Non-home real estate & 28.3 & 48.6 & 23.1 & 100.0 & 76.3 & 79.6 & 83.0 & 78.7 & 74.9 & 78.5 & 79.4 & 76.9 \\
\hline Total for group & 49.7 & 38.1 & 12.2 & 100.0 & 85.6 & 85.7 & 87.6 & 87.5 & 86.2 & 85.5 & 85.6 & 87.8 \\
\hline $\begin{array}{l}\text { Stocks, directly or } \\
\text { indirectly owned }^{\mathrm{a}}\end{array}$ & 38.3 & 42.9 & 18.8 & 100.0 & 89.7 & 80.8 & 78.7 & 81.9 & 78.7 & 76.9 & 78.8 & 81.2 \\
\hline \multicolumn{13}{|c|}{ B. Housing, Liquid Assets, Pension Assets, and Debt } \\
\hline Principal residence & 9.4 & 29.2 & 61.5 & 100.0 & 34.2 & 34.0 & 36.0 & 31.7 & 35.2 & 37.0 & 38.0 & 38.5 \\
\hline Deposits $^{b}$ & 20.2 & 37.5 & 42.3 & 100.0 & 52.9 & 61.5 & 59.7 & 62.3 & 51.0 & 57.2 & 60.9 & 57.7 \\
\hline Life insurance & 22.0 & 32.9 & 45.1 & 100.0 & 33.6 & 44.6 & 45.0 & 44.9 & 52.8 & 46.0 & 57.3 & 54.9 \\
\hline Pension accounts ${ }^{\mathrm{c}}$ & 14.4 & 44.8 & 40.8 & 100.0 & 67.5 & 50.5 & 62.3 & 62.3 & 59.8 & 60.4 & 58.3 & 59.2 \\
\hline Total for group & 12.0 & 33.8 & 54.2 & 100.0 & 41.0 & 43.9 & 45.2 & 42.5 & 44.0 & 45.9 & 45.7 & 45.8 \\
\hline Total debt & 5.4 & 21.3 & 73.4 & 100.0 & 31.8 & 29.4 & 37.5 & 28.3 & 27.0 & 25.9 & 27.0 & 26.6 \\
\hline \multicolumn{13}{|c|}{$\begin{array}{l}\text { Source: Own computations from the Survey of Consumer Finances } \\
\text { Households are classified into wealth class according to their net worth. Brackets for } 2007 \text { are: } \\
\text { Top } 1 \text { percent: Net worth of } \$ 8,232,000 \text { or more } \\
\text { Next } 9 \text { percent: Net worth between } \$ 883,800 \text { and } \$ 8,232,000 \\
\text { Bottom } 90 \text { Percent: Net worth less than } \$ 883,800 \\
\text { a. Includes direct ownership of stock shares and indirect ownership through mutual funds, } \\
\text { trusts, IRAs, Keogh plans, } 401(\mathrm{k}) \text { plans, and other retirement accounts. } \\
\text { b. Includes demand deposits, savings deposits, time deposits, money market funds, and } \\
\text { certificates of deposit. } \\
\text { c. IRAs, Keogh plans, } 401(\mathrm{k}) \text { plans, the accumulated value of defined-contribution pension } \\
\text { plans, and other retirement accounts. }\end{array}$} \\
\hline
\end{tabular}


Table 10. Household Income and Wealth by Race, 1983-2007

(in thousands, 2007 dollars)

\begin{tabular}{|ccccccc} 
& \multicolumn{3}{c}{ Means } & & \multicolumn{2}{c}{ Medians } \\
\cline { 2 - 3 } Year & Non-Hispanic & Non-Hispanic & & & Non-Hispanic & Non-Hispanic \\
Whites & African-Americans & Ratio & & Whites & African-Americans & Ratio \\
\hline
\end{tabular}

\section{A. Income}

1982

1988

1991

1994

1997

2000

2003

2006

B. Net Worth

$1983 \quad 316.0$

1989

1992

1995

1998

2001

2004

2007

C. Non-home Wealth

$\begin{array}{ll}1983 & 232.8 \\ 1989 & 282.6 \\ 1992 & 278.5 \\ 1995 & 256.4 \\ 1998 & 324.1 \\ 2001 & 432.8 \\ 2004 & 441.8 \\ 2007 & 495.3\end{array}$

D. Homeownership Rate (in percent)

1983

1989

1992

1995

1998

2001

2004

2007
68.1

69.3

69.0

69.4

71.8

74.1

75.8

74.8
34.9

31.6

35.3

31.3

36.2

43.0

41.8

44.6

59.5

62.7

67.2

55.5

74.1

77.7

111.3

122.7

30.0

30.7

38.3

28.9

47.8

50.6

67.5

70.7

44.3

41.7

48.5

46.8

46.3

47.4

50.1

48.6
0.54

0.45

0.50

0.48

0.49

0.48

0.49

0.48

0.19

0.17

0.19

0.17

0.18

0.14

0.19

0.19

0.13

0.11

0.14

0.11

0.15

0.12

0.15

0.14

0.65

0.60

0.70

0.67

0.64

0.64

0.66

0.65

E. Percent of Households with Zero or Negative Net Worth

\begin{tabular}{llll}
\hline 1983 & 11.3 & 34.1 & 3.01 \\
1989 & 12.1 & 40.7 & 3.38 \\
1992 & 13.8 & 31.5 & 2.28 \\
1995 & 15.0 & 31.3 & 2.09 \\
1998 & 14.8 & 27.4 & 1.85 \\
2001 & 13.1 & 30.9 & 2.35 \\
2004 & 13.0 & 29.4 & 2.27 \\
2007 & 14.5 & 33.4 & 2.30
\end{tabular}

Source: Own computations from the 1983, 1989 1992, 1995, 1998, 2001, 2004, and 2007 SCF.

Households are divided into four racial/ethnic groups: (i) non-Hispanic whites; (ii) non-Hispanic blacks; (iii) Hispanics; and (iv) American Indians, Asians, and others. For 1995, 1998, and 2001, the classification

scheme does not explicitly indicate non-Hispanic whites and non-Hispanic blacks for the first two categories

so that some Hispanics may have classified themselves as either whites or blacks. 
Table 11. Family Income and Wealth for Non-Hispanic Whites and Hispanics, 1983-2007 (in thousands, 2007 dollars)

\begin{tabular}{|c|c|c|c|c|c|c|}
\hline \multirow[b]{2}{*}{ Year } & \multicolumn{3}{|c|}{ Means } & \multicolumn{3}{|c|}{ Medians } \\
\hline & $\begin{array}{c}\text { Non-Hispanic } \\
\text { Whites }\end{array}$ & Hispanics & Ratio & $\begin{array}{c}\text { Non-Hispanic } \\
\text { Whites } \\
\end{array}$ & Hispanics & Ratio \\
\hline \multicolumn{7}{|c|}{ A. Income } \\
\hline 1982 & 64.8 & 39.2 & 0.60 & 45.6 & 30.2 & 0.66 \\
\hline 1988 & 71.0 & 32.4 & 0.46 & 47.3 & 22.7 & 0.48 \\
\hline 1991 & 70.6 & 33.3 & 0.47 & 43.5 & 23.2 & 0.53 \\
\hline 1994 & 64.8 & 42.0 & 0.65 & 43.5 & 29.9 & 0.69 \\
\hline 1997 & 73.6 & 39.6 & 0.54 & 47.1 & 29.3 & 0.62 \\
\hline 2000 & 88.9 & 44.0 & 0.50 & 51.5 & 28.1 & 0.55 \\
\hline 2003 & 85.4 & 42.2 & 0.49 & 52.7 & 28.5 & 0.54 \\
\hline 2006 & 92.3 & 46.4 & 0.50 & 50.0 & 35.0 & 0.70 \\
\hline \multicolumn{7}{|c|}{ B. Net Worth } \\
\hline 1983 & 316.0 & 51.4 & 0.16 & 91.0 & 3.5 & 0.04 \\
\hline 1989 & 373.9 & 61.5 & 0.16 & 108.1 & 2.3 & 0.02 \\
\hline 1992 & 361.8 & 80.4 & 0.22 & 90.7 & 5.4 & 0.06 \\
\hline 1995 & 329.7 & 69.8 & 0.21 & 83.0 & 6.8 & 0.08 \\
\hline 1998 & 408.2 & 100.8 & 0.25 & 103.9 & 3.8 & 0.04 \\
\hline 2001 & 545.3 & 93.8 & 0.17 & 124.6 & 3.5 & 0.03 \\
\hline 2004 & 586.1 & 125.6 & 0.21 & 129.8 & 6.1 & 0.05 \\
\hline 2007 & 652.1 & 170.4 & 0.26 & 143.6 & 9.1 & 0.06 \\
\hline \multicolumn{7}{|c|}{ C. Non-home Wealth } \\
\hline 1983 & 232.8 & 15.2 & 0.07 & 25.3 & 0.0 & 0.00 \\
\hline 1989 & 282.6 & 30.1 & 0.11 & 34.2 & 0.0 & 0.00 \\
\hline 1992 & 278.5 & 51.7 & 0.19 & 27.9 & 0.0 & 0.00 \\
\hline 1995 & 256.4 & 39.8 & 0.16 & 24.6 & 0.0 & 0.00 \\
\hline 1998 & 324.1 & 64.1 & 0.20 & 47.8 & 0.0 & 0.00 \\
\hline 2001 & 432.8 & 60.3 & 0.14 & 49.3 & 0.3 & 0.01 \\
\hline 2004 & 441.8 & 73.5 & 0.17 & 39.6 & 0.1 & 0.00 \\
\hline 2007 & 495.3 & 96.3 & 0.19 & 43.6 & 0.4 & 0.01 \\
\hline \multicolumn{7}{|c|}{ D. Homeownership Rate (in percent) } \\
\hline 1983 & 68.1 & 32.6 & 0.65 & & & \\
\hline 1989 & 69.3 & 39.8 & 0.60 & & & \\
\hline 1992 & 69.0 & 43.1 & 0.70 & & & \\
\hline 1995 & 69.4 & 44.4 & 0.67 & & & \\
\hline 1998 & 71.8 & 44.2 & 0.67 & & & \\
\hline 2001 & 74.1 & 44.3 & 0.60 & & & \\
\hline 2004 & 75.8 & 47.7 & 0.63 & & & \\
\hline 2007 & 74.8 & 49.2 & 0.66 & & & \\
\hline \multicolumn{7}{|c|}{ E. Percent of Households with Zero or Negative Net } \\
\hline \multicolumn{7}{|c|}{ Worth } \\
\hline 1983 & 11.3 & 40.3 & 3.01 & & & \\
\hline 1989 & 12.1 & 39.9 & 3.38 & & & \\
\hline 1992 & 13.8 & 41.2 & 2.28 & & & \\
\hline 1995 & 15.0 & 38.3 & 2.09 & & & \\
\hline 1998 & 14.8 & 36.2 & 2.09 & & & \\
\hline 2001 & 13.1 & 35.3 & 2.69 & & & \\
\hline 2004 & 13.0 & 31.3 & 2.41 & & & \\
\hline 2007 & 14.5 & 33.5 & 2.30 & & & \\
\hline
\end{tabular}




\begin{tabular}{|c|c|c|c|c|c|c|c|c|}
\hline Age & 1983 & 1989 & 1992 & 1995 & 1998 & 2001 & 2004 & 2007 \\
\hline \multicolumn{9}{|c|}{ A. Mean Net Worth (ratio to overall mean) } \\
\hline Overall & 1.00 & 1.00 & 1.00 & 1.00 & 1.00 & 1.00 & 1.00 & 1.00 \\
\hline Under 35 & 0.21 & 0.29 & 0.20 & 0.16 & 0.22 & 0.19 & 0.14 & 0.17 \\
\hline $35-44$ & 0.71 & 0.72 & 0.71 & 0.65 & 0.68 & 0.64 & 0.65 & 0.58 \\
\hline 45-54 & 1.53 & 1.50 & 1.42 & 1.39 & 1.27 & 1.25 & 1.21 & 1.19 \\
\hline $55-64$ & 1.67 & 1.58 & 1.82 & 1.81 & 1.91 & 1.86 & 1.91 & 1.69 \\
\hline 65-74 & 1.93 & 1.61 & 1.59 & 1.71 & 1.68 & 1.72 & 1.57 & 1.86 \\
\hline 75 and over & 1.05 & 1.26 & 1.20 & 1.32 & 1.12 & 1.20 & 1.19 & 1.16 \\
\hline \multicolumn{9}{|c|}{ B. Mean Non-home Wealth (ratio to overall mean) } \\
\hline Overall & 1.00 & 1.00 & 1.00 & 1.00 & 1.00 & 1.00 & 1.00 & 1.00 \\
\hline Under 35 & 0.17 & 0.28 & 0.18 & 0.14 & 0.21 & 0.19 & 0.12 & 0.15 \\
\hline $35-44$ & 0.59 & 0.68 & 0.69 & 0.62 & 0.67 & 0.61 & 0.64 & 0.54 \\
\hline $45-54$ & 1.53 & 1.48 & 1.45 & 1.43 & 1.31 & 1.27 & 1.24 & 1.19 \\
\hline $55-64$ & 1.72 & 1.60 & 1.89 & 1.86 & 1.99 & 1.94 & 1.97 & 1.80 \\
\hline 65-74 & 2.12 & 1.69 & 1.60 & 1.75 & 1.66 & 1.74 & 1.61 & 1.86 \\
\hline 75 and over & 1.10 & 1.27 & 1.14 & 1.26 & 1.00 & 1.11 & 1.08 & 1.10 \\
\hline \multicolumn{9}{|c|}{ C. Homeownership Rate (in percent) } \\
\hline Overall & 63.40 & 62.80 & 64.10 & 64.70 & 66.30 & 67.70 & 69.10 & 68.60 \\
\hline Under 35 & 38.70 & 36.30 & 36.80 & 37.90 & 39.20 & 40.20 & 41.50 & 40.80 \\
\hline $35-44$ & 68.40 & 64.10 & 64.40 & 64.70 & 66.70 & 67.60 & 68.60 & 66.10 \\
\hline $45-54$ & 78.20 & 75.10 & 75.50 & 75.40 & 74.50 & 76.10 & 77.30 & 77.30 \\
\hline $55-64$ & 77.00 & 79.20 & 77.90 & 82.30 & 80.60 & 83.20 & 79.10 & 80.90 \\
\hline $65-74$ & 78.30 & 78.10 & 78.80 & 79.40 & 81.70 & 82.50 & 81.20 & 85.50 \\
\hline 75 and over & 69.40 & 70.20 & 78.10 & 72.50 & 76.90 & 76.20 & 85.10 & 77.00 \\
\hline
\end{tabular}




\begin{tabular}{|c|c|c|c|c|c|c|c|}
\hline \multicolumn{8}{|c|}{$\begin{array}{l}\text { Table 13. Composition of Household Wealth by Age Class, } 2007 \\
\text { (Percent of gross assets) }\end{array}$} \\
\hline Asset & All & Under 35 & 35-44 & 45-54 & $55-64$ & 65-74 & $75+$ \\
\hline Principal residence & 32.8 & 54.3 & 43.7 & 33.8 & 25.6 & 28.2 & 30.2 \\
\hline $\begin{array}{l}\text { Liquid assets (bank deposits, money } \\
\text { market funds, and cash surrender } \\
\text { value of life insurance) }\end{array}$ & 6.6 & 5.7 & 5.4 & 6.4 & 6.3 & 6.1 & 10.5 \\
\hline Pension accounts & 12.1 & 6.0 & 10.7 & 13.0 & 15.8 & 12.9 & 5.0 \\
\hline $\begin{array}{l}\text { Corporate stock, financial securities, } \\
\text { mutual funds, and personal trusts }\end{array}$ & 15.5 & 4.2 & 8.6 & 13.1 & 16.4 & 20.5 & 25.6 \\
\hline $\begin{array}{l}\text { Unincorporated business equity and } \\
\text { other real estate }\end{array}$ & 31.3 & 28.7 & 30.1 & 32.0 & 34.4 & 30.2 & 27.1 \\
\hline Miscellaneous assets & 1.7 & 1.2 & 1.5 & 1.7 & 1.5 & 2.1 & 1.6 \\
\hline Total assets & 100.0 & 100.0 & 100.0 & 100.0 & 100.0 & 100.0 & 100.0 \\
\hline \multicolumn{8}{|l|}{ Memo (selected ratios in percent) } \\
\hline$\overline{\text { Debt/equity ratio }}$ & 18.1 & 92.7 & 41.3 & 20.2 & 11.9 & 7.1 & 2.1 \\
\hline Debt/income ratio & 118.7 & 167.5 & 156.5 & 118.2 & 100.0 & 79.7 & 29.9 \\
\hline Net home equity/total assets ${ }^{\mathrm{a}}$ & 21.4 & 18.8 & 21.3 & 20.9 & 18.1 & 23.4 & 28.7 \\
\hline Principal residence debt/house value & 34.9 & 65.4 & 51.4 & 38.3 & 29.2 & 16.9 & 4.9 \\
\hline All stocks/total assets ${ }^{\mathrm{b}}$ & 16.8 & 5.9 & 11.2 & 15.1 & 19.4 & 21.5 & 20.0 \\
\hline
\end{tabular}

Source: Own computations from the 2007 Survey of Consumer Finances. Households are classified into age class according to the age of the household head.

a. Ratio of gross value of principal residence less mortgage debt on principal residence to total assets.

b. Includes direct ownership of stock shares and indirect ownership through mutual funds, trusts, IRAs, Keogh plans, 401(k) plans, and other retirement accounts.

c. Financial securities exclude U.S. government savings bonds in this tabulation. 


\begin{tabular}{|c|c|c|c|}
\hline \multicolumn{4}{|c|}{$\begin{array}{l}\text { Table 14a. Stock Ownership, } 1983 \text { and } 1989 \\
\text { (percent of households holding stocks) }\end{array}$} \\
\hline Stock Type & 1983 & 1989 & 1983-1989 \\
\hline Direct stock holdings only & 13.7 & 13.1 & \\
\hline \multicolumn{4}{|l|}{ Stocks and Mutual Funds } \\
\hline 1. Any holdings & 24.4 & 19.9 & \\
\hline 2. Holdings worth $\$ 5,000$ or more ${ }^{a}$ & 14.5 & 14.6 & \\
\hline 3. Holdings worth $\$ 10,000$ or more ${ }^{a}$ & 10.8 & 12.3 & \\
\hline 4. Holdings worth $\$ 25,000$ or more ${ }^{a}$ & 6.2 & 8.4 & \\
\hline \multicolumn{4}{|l|}{ Memo } \\
\hline $\begin{array}{l}\text { Stocks plus mutual funds as a percent } \\
\text { of total assets }\end{array}$ & 9.0 & 6.9 & \\
\hline $\begin{array}{l}\text { Percentage change in S\&P } 500 \text { Index, } \\
\text { in constant dollars over period }\end{array}$ & & & 61.7 \\
\hline
\end{tabular}

\begin{tabular}{|c|c|c|c|c|c|c|c|c|}
\hline \multicolumn{9}{|c|}{$\begin{array}{l}\text { Table 14b. Stock Ownership, 1989-2007 } \\
\text { (percent of households holding stocks) }\end{array}$} \\
\hline Stock Type & 1989 & 1992 & 1995 & 1998 & 2001 & 2004 & 2007 & 1989-2007 \\
\hline Direct stock holdings only & 13.1 & 14.8 & 15.2 & 19.2 & 21.3 & 20.7 & 17.9 & \\
\hline Indirect Stock Holdings Only & 23.5 & 29.3 & 34.8 & 43.4 & 47.7 & 44.0 & 44.4 & \\
\hline 1. Through mutual funds & 5.9 & 8.4 & 11.3 & 15.2 & 16.7 & 14.1 & 10.6 & \\
\hline 2. Through pension accounts & 19.5 & 24.8 & 29.2 & 37.4 & 41.4 & 38.0 & 40.2 & \\
\hline 3. Through trust funds & 1.6 & 1.2 & 1.9 & 2.4 & 5.1 & 4.7 & 4.1 & \\
\hline \multicolumn{9}{|l|}{ All Stock Holdings $^{\mathrm{a}}$} \\
\hline 1. Any holdings & 31.7 & 37.2 & 40.4 & 48.2 & 51.9 & 48.6 & 49.1 & \\
\hline 2. Stock worth $\$ 5,000$ or more ${ }^{b}$ & 22.6 & 27.3 & 29.5 & 36.3 & 40.1 & 34.9 & 34.6 & \\
\hline 3. Stock worth $\$ 10,000$ or more ${ }^{b}$ & 18.5 & 21.8 & 23.9 & 31.8 & 35.1 & 29.8 & 29.6 & \\
\hline 4. Stock worth $\$ 25,000$ or more ${ }^{b}$ & 10.5 & 13.1 & 16.6 & 24.3 & 27.1 & 22.5 & 22.1 & \\
\hline \multicolumn{9}{|l|}{ Memo } \\
\hline $\begin{array}{l}\text { Direct plus indirect stocks as a percent } \\
\text { of total assets }\end{array}$ & 10.2 & 13.7 & 16.8 & 22.6 & 24.5 & 17.5 & 16.8 & \\
\hline $\begin{array}{l}\text { Percentage change in S\&P } 500 \text { Index, } \\
\text { in constant dollars over period }\end{array}$ & & 13.8 & 20.0 & 87.3 & 1.3 & -11.2 & 19.0 & 173.6 \\
\hline \multicolumn{9}{|c|}{$\begin{array}{l}\text { Source: Own computations from the } 1989,1992,1995,1998,2001,2004 \text {, and } 2007 \text { Survey of Consumer Finances. } \\
\text { a. Includes direct ownership of stock shares and indirect ownership through mutual funds, } \\
\text { trusts, IRAs, Keogh plans, } 401(\mathrm{k}) \text { plans, and other retirement accounts. } \\
\text { b. } 1995 \text { dollars }\end{array}$} \\
\hline
\end{tabular}




\begin{tabular}{|c|c|c|c|c|c|c|c|c|}
\hline \multicolumn{9}{|c|}{$\begin{array}{l}\text { Table 14c. Distribution of Stock Ownership by Asset Type, 1989-2007 } \\
\text { (percent of total stock held in each asset type) }\end{array}$} \\
\hline Stock Type & 1989 & 1992 & 1995 & 1998 & 2001 & 2004 & 2007 & $\begin{array}{l}\text { Change } \\
\text { 1989-2007 }\end{array}$ \\
\hline Direct stock holdings & 54.0 & 49.4 & 36.7 & 42.6 & 38.5 & 37.1 & 37.1 & -16.9 \\
\hline Indirect Stock Holdings Only & 46.0 & 50.6 & 63.3 & $\mathbf{5 7 . 4}$ & 61.5 & 62.9 & 62.9 & 16.9 \\
\hline 1. Through mutual funds & 8.5 & 10.9 & 17.9 & 16.3 & 16.0 & 21.9 & 21.3 & 12.8 \\
\hline 2. Through pension accounts & 24.4 & 34.1 & 37.9 & 32.9 & 33.5 & 30.9 & 31.4 & 7.0 \\
\hline 3. Through trust funds & 13.2 & 5.6 & 7.6 & 8.2 & 12.0 & 8.1 & 7.2 & -6.0 \\
\hline \multicolumn{9}{|l|}{ Memo } \\
\hline $\begin{array}{l}\text { Stocks held in pension accounts/ } \\
\text { total value of pension accounts }\end{array}$ & 32.6 & 44.8 & 67.5 & 64.1 & 66.3 & 45.6 & 43.6 & 11.1 \\
\hline
\end{tabular}




\begin{tabular}{|c|c|c|c|c|c|c|}
\hline \multirow[b]{3}{*}{ Wealth Class } & \multicolumn{3}{|c|}{$\begin{array}{l}\text { Percent of Households Owning } \\
\text { Stock Worth More Than: }\end{array}$} & \multicolumn{3}{|c|}{ Percent of Stock Owned } \\
\hline & \multirow[b]{2}{*}{ Zero } & \multirow[b]{2}{*}{$\$ 4,999$} & \multirow[b]{2}{*}{$\$ 9,999$} & \multicolumn{3}{|c|}{ Cumulativ } \\
\hline & & & & Shares & e & Cumulative-2001 \\
\hline Top 1 percent & 92.6 & 89.1 & 88.4 & 38.3 & 38.3 & 33.5 \\
\hline Next 4 percent & 92.2 & 90.7 & 89.5 & 30.8 & 69.1 & 62.3 \\
\hline Next 5 percent & 86.8 & 85.0 & 81.4 & 12.1 & 81.2 & 76.9 \\
\hline Next 10 percent & 82.1 & 77.1 & 71.2 & 9.9 & 91.1 & 89.3 \\
\hline Second quintile & 65.4 & 54.3 & 47.1 & 6.4 & 97.5 & 97.1 \\
\hline Third quintile & 47.7 & 28.9 & 22.1 & 1.9 & 99.4 & 99.3 \\
\hline Fourth quintile & 30.3 & 12.3 & 8.7 & 0.5 & 99.9 & 99.8 \\
\hline Bottom quintile & 16.3 & 3.5 & 2.0 & 0.1 & 100.0 & 100.0 \\
\hline All & 49.1 & 36.3 & 31.6 & 100.0 & & \\
\hline
\end{tabular}

Table 15b. Concentration of Stock Ownership by Income Class, 2007

\begin{tabular}{|c|c|c|c|c|c|c|c|}
\hline \multirow{2}{*}{ Income Level } & \multirow{2}{*}{$\begin{array}{c}\text { Share of } \\
\text { Households }\end{array}$} & \multicolumn{3}{|c|}{$\begin{array}{c}\text { Percent of Households Owning } \\
\text { Stock Worth More Than: }\end{array}$} & \multicolumn{3}{|c|}{ Percent of Stock Owned } \\
\hline & & & & & & mulati & \\
\hline$\$ 250,000$ or more & 3.6 & 95.4 & 93.4 & 91.3 & 53.7 & 53.7 & 40.6 \\
\hline$\$ 100,000-249,999$ & 15.5 & 84.5 & 71.0 & 63.7 & 21.5 & 75.2 & 68.6 \\
\hline$\$ 75,000-99,999$ & 10.4 & 71.1 & 55.6 & 49.6 & 9.0 & 84.3 & 77.4 \\
\hline$\$ 25,000-49,999$ & 27.1 & 39.3 & 23.6 & 19.0 & 5.7 & 97.7 & 97.6 \\
\hline$\$ 15,000-24,999$ & 12.7 & 23.1 & 15.7 & 11.9 & 1.1 & 98.8 & 98.9 \\
\hline Under $\$ 15,000$ & 13.3 & 11.2 & 5.0 & 4.3 & 1.2 & 100.0 & 100.0 \\
\hline All & 100.0 & 49.1 & 36.3 & 31.8 & 100.0 & & \\
\hline
\end{tabular}

Note: Includes direct ownership of stock shares and indirect ownership through mutual funds, trusts,

IRAs, Keogh plans, 401(k) plans, and other retirement accounts. All figures are in 2007 dollars. 